NBER WORKING PAPER SERIES

\title{
EMPIRICS ON THE ORIGINS OF PREFERENCES: THE CASE OF COLLEGE MAJOR AND RELIGIOSITY
}

\author{
Miles S. Kimball \\ Colter M. Mitchell \\ Arland D. Thornton \\ Linda C. Young-Demarco \\ Working Paper 15182 \\ http://www.nber.org/papers/w15182
NATIONAL BUREAU OF ECONOMIC RESEARCH
1050 Massachusetts Avenue
Cambridge, MA 02138
July 2009

The authors acknowledge the contributions of Jerald Bachman, Lloyd Johnson, Patrick O'Malley, John Schulenberg, Shelly Yee, and Jonathon Brenner in collecting the Monitoring the Future data and making it available for this project. We also appreciate the crucial financial support of the John Templeton Foundation, which funded the efforts of all four coauthors on this paper. Julie de Jong, Jenna Keedy, Judy Baughn, and Jana Bruce provided helpful assistance in data analysis, manuscript preparation, and project administration. While we thank each of these individuals and organizations for their contributions, responsibility for all errors of fact and interpretation remain with the authors. The views expressed herein are those of the author(s) and do not necessarily reflect the views of the National Bureau of Economic Research.

NBER working papers are circulated for discussion and comment purposes. They have not been peerreviewed or been subject to the review by the NBER Board of Directors that accompanies official NBER publications.

(C) 2009 by Miles S. Kimball, Colter M. Mitchell, Arland D. Thornton, and Linda C. Young-Demarco. All rights reserved. Short sections of text, not to exceed two paragraphs, may be quoted without explicit permission provided that full credit, including $\odot$ notice, is given to the source. 
Empirics on the Origins of Preferences: The Case of College Major and Religiosity

Miles S. Kimball, Colter M. Mitchell, Arland D. Thornton, and Linda C. Young-Demarco

NBER Working Paper No. 15182

July 2009

JEL No. I2,J1,Z11,Z12,Z13

\begin{abstract}
$\underline{\text { ABSTRACT }}$
Early life experiences are likely to be important for the formation of preferences. Religiosity is a key dimension of preferences, affecting many economic outcomes. This paper examines the effect of college major on religiosity, and the converse effect of religiosity on college major, using panel data from the Monitoring the Future survey as a way of gauging the extent to which various streams of thought, as taught in college, affect religiosity. Two key questions, based on the differences in college experience across majors, are whether either (a) the Scientific worldview or (b) Postmodernism has negative effects on religiosity as these streams of thought are actually transmitted at the college level. The results show a decline in religiosity of students majoring in the social sciences and humanities, but a rise in religiosity for those in education and business. After initial choices, those respondents with high levels of religiosity are more likely to enter college. Of those who are in college, people with high levels of religiosity tend to go into the humanities and education over other majors.
\end{abstract}

Miles S. Kimball

Department of Economics

University of Michigan

Ann Arbor, MI 48109-1220

and NBER

mkimball@umich.edu

Colter M. Mitchell

Family Demography

Survey Research Center

University of Michigan

Ann Arbor, MI 48109-1248

cmsm@umich.edu
Arland D. Thornton

Survey Research Center

2226 ISR, University of Michigan,

Ann Arbor, MI 48109-1248

arlandt@umich.edu

Linda C. Young-Demarco

Survey Research Center

ISR 2270, University of Michigan

Ann Arbor, Michigan, 48109-1248

lyoungdm@umich.edu 


\section{Introduction}

In economic theory, the trinity of preferences, technology and the structure of strategic interactions (including information structures) generates economic behavior, while this trinity plus chance generates economic outcomes. A deep understanding of Economics requires answer to the three origin questions: "What determines the level of technology?" "What determines the structure of strategic interactions?" and "How are preferences determined?" In this paper, we address one dimension of this third question about the determinants of preferences, focusing on those aspects of preferences associated with religion.

To the extent that preferences are determined by nature and genetics, questions about the origin of preferences border on Evolutionary Psychology. On the other hand, to the extent that preferences depend on nurture and culture, questions about the origin of preferences border on Developmental Psychology and Sociology. Sociologists often use the term "values" where economists would use the term "preferences." (We will use the terms interchangeably.) Among the dimensions of preferences determined primarily by nurture and culture, those associated with religion bulk large in importance. ${ }^{1}$ Emphasizing the Economics literature, and to a lesser extent the Sociology literature, religiosity and religious affiliation have been related, among other things, to education (Freeman, 1986; Claudia Goldin and Lawrence Katz, 1999; Lehrer, 2004; Kraig Beyerlein, 2004), employment and work hours (Richard Freeman, 1986) wages, income and wealth accumulation (Claudia Goldin and Lawrence Katz, 2000; Lisa Keister, 2003; Evelyn Lehrer, 2004a,b); mate choice, cohabitation, marital stability, fertility and female labor force participation (Thornton et al 2007; Lehrer, 2004a; Charles Manski and Joram Mayshar, 2002); intergenerational transfers (Scott Myers, 2004), tobacco use (Frank Chaloupka, Michael Grossman and John Tauras, 1997; Chaloupka and Grossman, 1997; Tauras and Chaloupka, 1999), alcohol use (Rosalie Pacula, 1998), substance abuse and other types of social deviance (Freeman, 1986; Pacula et al., 2000; Richard Gorsuch, 1995), suicide (Emile Durkheim, 1897), child abuse (Sara Markowitz and Grossman, 1996), physical and mental health (David Williams, et al. 1991; Valerie Dull and Laurie Skokan, 1995; W. Larry Ventis, 1995; Christopher Ellison, 1998; Jeffrey Levin and Robert Taylor, 1998), subjective well-being (David Blanchflower and Andrew Oswald, 1997; Jeffrey Levin and Robert Taylor, 1998), organ donation (Naci Mocan and Erdal Tekin, 2005), work ethic

\footnotetext{
${ }^{1}$ Given the limitations of our data, we will not be able to separate differences in religious preferences from differences in religious beliefs, so we will not emphasize this distinction and treat religious differences as a matter of preferences. In terms of effects on choices, there is a high degree of substitutability between differences in religious beliefs and differences in religious preferences. It is likely, though, that the cognitive or belief element of religious differences is particularly susceptible to being affected by education. Thus, a deep microtheoretical explanation of how the mechanisms we identify in this paper operate would require one to deal more fully with the beliefs/preferences distinction in a religious context. Such a micro-theoretical explanation of how people's religious beliefs and preferences are altered is beyond the scope of this paper; the job we have taken on is attempting to identify some of the effects that would need to be explained by such a theory.
}

James Montgomery (1996) discusses the issue of whether religious differences are matters of belief or matters of preferences. He argues that, to the extent religious beliefs are not governed by common knowledge and Bayesian updating, that the distinction is not as central a theoretical distinction as it is in areas where beliefs are governed by common knowledge (at some point), plus Bayesian updating (perhaps with private information). Although a Bayesian approach can be quite useful in judging religious beliefs within a culture that admits only a few different possible religious beliefs, in general it faces the difficulty that it would be almost impossible to specify a reasonable prior probability distribution over all possible structures of ultimate reality. Even in scientific contexts, the difficult of specifying an adequate prior probability distribution over all possible structures of ultimate reality is an important argument for Frequentists in their ongoing argument with strict Bayesians.

Pascal's Wager (see the Stanford Encyclopedia of Philosophy http://plato.stanford.edu/entries/pascal-wager/ ) is a good illustration of how easily preferences and probability can get mixed up in a religious context. Pascal's Wager is the (still often influential) argument that one should believe in God because the cost of believing in God if in fact there is no God is small, while the cost of not believing in God if in fact there is a God is large. Note how this argument assumes one can and should choose optimal beliefs rather than using Bayesian updating and in its simplest statement assumes a prior with only two major possibilities for the structure of ultimate reality. 
(Robert Barro and Rachel McCleary, 2006), trust, attitudes about lawbreaking and about the fairness of the market (Luigi Guiso, Paola Sapienza and Luigi Zingales, 2002, 2006), political differences (Edward L. Glaeser and Bryce Ward, 2005) and the preferences reflected in the individually assessed importance of recognition, ambition, accomplishment, being capable, comfort, pleasure, excitement, personal independence, intellectuality, being logical, freedom, peace, beauty, helpfulness, forgiveness, lovingness, honesty, salvation, obedience, and security (Shalom Shwartz and Sipke Huismans, 1995). We include in this list analyses that treated religiosity or religious affiliation as control variables, rather than as the main subject of analysis, as long as they found statistically significant effects of religiosity or religious affiliation. It should also be noted that religiosity and religious affiliation are often associated with preferences for mystical experience and notional supernatural goods (Rodney Stark and William Bainbridge, 1987).

There have been a number of serious efforts to identify the causal effects of religiosity and religious affiliation. Jonathan Gruber (2005) uses the local density of other ethnic groups that share an individual's religion as an instrument for religiosity. He finds that the additional religiosity due to higher market density of one's own religion leads on average to "higher levels of education and income, lower levels of welfare receipt, higher levels of marriage, and lower levels of divorce." Robert Barro and Rachel McCleary $(2002,2003)$ use differences across countries in the presence of a state religion, state regulation of religion, a measure of religious pluralism and religious composition as instruments for church attendance and belief in an afterlife. They find that in the dimensions scoped out by the instruments, economic growth depends on the extent of believing in an afterlife relative to the level of religious attendance. ${ }^{2}$

One possible definition of religion could be that religion is the process by which human beings determine what their ultimate values are, to the extent that those ultimate values go beyond what are determined genetically. In other words, it would not be entirely unreasonable to define religion as the cultural component of the determination of preferences. However, this definition, by itself, is too broad for our purposes, since it does not explain the difference visible in observed behavior between those individuals with high levels of religiosity and those with low levels of religiosity.

For our purposes, the view of religion given by Durkheim (1915) provides a helpful perspective. Durkheim argues that religions are functional organizations that use striking ideas to foster collective action and the interests of the religious community as a community, including influence over both daily interactions among members and relationships with those outside. This view has been taken up more recently by the evolutionary theorist David Sloan Wilson (2002).

Concepts from biological evolutionary theory can be helpful even in studying Cultural Evolution. For example, even preferences determined primarily by nurture and culture are subject to demographic selection pressure as potential parents with certain characteristics have more children than those with other characteristics, and raise them to have somewhat similar characteristics. In the case of religious preferences, based on the positive relationship between religiosity and fertility, it is clear that for at least the last century, demographic selection pressure toward the preferences of especially prolific parents would operate in the direction of greater religiosity. Indeed, this is one of the key forces helping to maintain a high level of religiosity in the United States.

\footnotetext{
2 They argue as follows: "These results accord with a perspective in which religious beliefs influence individual traits that enhance economic performance. The beliefs are, in turn, the principal output of the religion sector, and church attendance measures the inputs to this sector. Hence, for given beliefs, more church attendance signifies more resources used up by the religion sector.
} 
Nevertheless, there have been periods of pronounced secularization in Europe and a relative steadiness in the United States of the overall level of religiosity even in the face of demographic pressure toward greater religiosity that suggests the existence of other important influences on religious preferences beyond parental influences. In this paper, we focus our empirical sights on one prime suspect: the influence of the college experience--which is often the first time people are separated from their parents for an extended period of time. Among nonparental influences on preferences, the college experience is one for which there is real hope of getting some statistical power from micro-data, as opposed to trying to look at unrepeatable macro shocks.

Human mortality guarantees that the fate of civilizations and cultures depends on how ideas are transmitted from one generation to the next. In the last few centuries, formal education has played an increasingly important role in this intergenerational transmission of ideas. One of the key aspects of higher education is that it comes at an age when students are able to compare and contrast a variety of streams of thought and to begin to forge their own individual worldviews out of these various streams of thought. How an idea fares at this nexus can have an important bearing on the degree of influence an idea will have in the culture. Indeed, in countries like the United States, the large fraction of the total population that attends college makes it possible to talk about mass intellectual culture---intellectual culture that is not the property of a few elites, but affects a large swath of society.

A great deal of research has found that college majors exhibit important correlations with values. ${ }^{3}$ One possible explanation is that students in different majors are exposed to strikingly different sets of ideas (not only from formal instruction but also from the extra time they spend with peers in the same major.) Another possible explanation is that students with different values sort differentially into different majors. We are interested in studying how the specific contents of the curriculum a student is exposed to (along with classmates) affect students' values during these formative years, carefully distinguishing these effects from patterns of selection into majors. To give a focus to these questions, we consider the effects of different college experiences on religiosity an appropriate place to start.

Bruce Sacerdote and Edward Glaeser (2001) document some of the effects of education on religiosity overall. They find that the effects are very different in different countries, which they conjecture is due to the different content of education in different countries. They use the following example: "Socialist countries appear to use the power of the state over education to quash religious beliefs. We interpret this as suggesting that the educationreligion connection is not intrinsic but rather a function of curriculum design and the objectives of those who control education." We argue that even within a single university, the curriculum and the objectives of those controlling it can be very different in different departments.

We hypothesize that students in college are confronted to varying degrees with at least three powerful streams of thought that bear on attitudes toward religion: Science, Developmentalism and Postmodernism. Science--or Scientism, to emphasize the worldview aspect--consists primarily of a commitment to truth, the scientific method and to an open-ended responsiveness to evidence. The pursuit of the scientific method has led to a particular picture of the universe that has important implications for religion. Developmentalism consists primarily of a commitment to freedom and to progress. Although these ideas are widely shared by Americans, many do not know the intellectual arguments that have historically undergirded the conviction of the importance of freedom and

\footnotetext{
${ }^{3}$ See for example Newcomb (1943), Newcomb et al. (1967), Thistlethwaite (1973), Duff and Cotgrove (1982), Biddle et al. (1990), Alwin et al. (1991), Easterlin and Crimmins (1991), Jennings (1993), Easterlin (1995), Hogner (1996), Kolenko et al. (1996), Zlotkowski (1996), Ethington and Wolfle (1988) Guimond (1999), Ridener (1999), Shiarella and McCarthy (2000), Leppel et al. (2001), Hodgkinson and Innes (2001), Sidanius et al. (2003), and Bécares and Turner (2004), Kimball, Mitchell, Thornton and Young De-Marco (2005).
} 
progress. Postmodernism consists primarily of a commitment to relativism and to the idea that truth and morality are not absolute but are determined by those who are powerful.

Each of these three streams of thought could interact in important ways with religious attitudes and values. For example, it seems reasonable to suppose that Science insists that religious beliefs be amenable to evidence. Developmentalism influences people toward optimistic rather than pessimistic religious attitudes and causes a focus on the practical benefits of religion as opposed to its other-worldly benefits alone. As for Postmodernism, a typical undergraduate might experience Postmodernism's commitment to relativism as hostile to religious claims to truth. (Postmodernism's commitment to relativism is also sometimes antagonistic to scientific claims to truth.) We return to a discussion of these tensions with religion in the following section.

College majors differ in important ways in the extent to which each major incorporates each stream of thought. The Humanities and some of the Social Sciences typically have a strong Postmodernist content. The Natural Sciences have a strong Scientist content. Economics and Business typically have a strong Developmentalist content. The different ideational content of different majors makes it possible to test at a practical level the three hypotheses that Postmodernism, Science and Developmentalism have a negative effect on religiosity by relating college major to religious attitudes, as well as attitudes toward science and relativism, one can see if the effects of these three streams of thought are as we hypothesize. Of course, while studying the effects of these three streams of thought motivates our analysis, studying the effects of different college majors on religiosity should be of interest even for those who have a different assessment of the ideational content of various college majors.

We will study the influence of college attendance and major field of study on religious participation and commitment using a unique data set, the Monitoring the Future Study. The Monitoring the Future Study is a University of Michigan project that is particularly valuable for our purposes because it has been studying high school students and their experiences following high school since 1975. Every year Monitoring the Future draws a large and representative sample of high school seniors in the United States. Each year about 16,000 students in approximately 133 public and private high schools nationwide are interviewed during their senior year of high school. Beginning with the class of 1976, a randomly-selected sample from each senior class has been followed up bi-annually after high school on a continuing basis. At each interview students are asked a wide range of questions, including their religious attendance and commitment. In addition, in each of the follow-up interviews information is obtained about college attendance and program of study. This panel study permits in-depth examination of religiosity and the way it is influenced by college experiences.

Our basic research strategy is to begin our analysis with the information from the study participants during their senior year in high school. This information provides us a baseline of information about religious participation and commitment at that point in the life course. Then, we will follow the students over the subsequent years of the important transition to adulthood and examine how religiosity changes. In particular, we will examine how changes in religiosity across a time period are affected by the amount and type of education experienced during that same period of time using latent growth curve analysis. This technique is similar in spirit to differences in differences analysis.

Our analysis of the converse effect of religiosity on the choice of college major is even closer to being a differences in differences analysis. We analyze the relationship between religiosity and changes in college major, breaking the process of changing a college major down into the two steps of (a) leaving one major and (b) choosing another.

An alternative strategy for identifying the effects of college major on religiosity in the face of nonrandom selection into college majors would be to find an instrumental variable for college major. But it is very difficult to isolate 
anything in our data set that would have a strong effect on college major that does not also have the potential to affect religiosity through other avenues besides college major (thereby making it an invalid instrument). Thus, an instrumental variable strategy is not feasible even with this comparatively rich data set (although it is conceivable in the context of a potential future data set collected from the beginning with an instrumental variable strategy in mind). Even if one were to design a data set for exactly that purpose, it is difficult to see what could be identified as an exogenous instrument. The best case would probably be for something like distance of home from colleges offering various different menus of majors. But residential sorting means that this would not be an exogenous instrument. For example, teenagers who live in college towns start out very different from teenagers who live outside college towns, and may have different expected trajectories quite apart from the effects of actually attending college themselves. ${ }^{4}$

Despite the absence of good instruments for college major, we believe that something useful can be learned from an approach based on controlling for the main confounding influences on religiosity and on the choice of college major. In our investigation of the effect of college major on religiosity, we believe that latent growth curve analysis will control for initial conditions somewhat better than simpler techniques by allowing initial conditions to predict different time paths rather than just levels.

\section{Theory of the Effect of Education on Religiosity}

Theory about the origin of preferences must be of a different kind than the more familiar theory of how those preferences interact with constraints and the structure of strategic interactions to determine behavior. Part of the different flavor arises from the fact that, as Richard Dawkins $(1976,2006)$ points out, the evolutionary principles of as-if maximization apply to any replicating entity, including individual genes and ideas as well as to whole organisms. Thus, there is not one maximizer (or quasi-maximizer), but many. Second, cultural evolution has not reached steady state, so some cultural entities that are quite unfit in terms of their own reproduction may not yet have been swept from the scene. More difficult still, we must assess the prospects various ideas have for maintaining and spreading themselves without direct information on a steady-state toward which everything is heading.

Consider the analogy of a company judging the likely profitability of a new technique. In the absence of sufficient direct data on the profitability of a new technique the company could resort to an a priori engineering and marketing assessment of its promise. This might then be followed by a marketing experiment. We are following an analogous procedure. The discussion immediately below amounts to an a priori assessment--at the culturalengineering and idea-marketing level--of the likely interactions of various ideas with one another. We then test these cultural engineering/idea-marketing assessments on our data.

Previous Literature on Education and Religiosity. An example of highly relevant cultural-engineering hypotheses in the Economics literature are the three alternative hypotheses laid out by Barro and McCleary (2002). The first hypothesis is the Science Drives out Superstition Hypothesis, which has been around at least since David Hume (1757). If religion reflects primarily ignorance, irrational fears, and superstition, then increased education could reduce religiosity by reducing ignorance and inculcating science. The idea that science drives out superstition is an important component of the Secularization Hypothesis. The second hypothesis is the Capacity for Abstraction Hypothesis, which Barro and McCleary attribute to a remark of Greg Mankiw. Mankiw proposes that understanding religious beliefs requires an ability to deal with abstractions, which can be fostered by education.

\footnotetext{
${ }^{4}$ Some countries may have had periods of random assignment of students to college majors. This could make very interesting analyses possible. But we believe that the ideational content of the various college majors in such countries would be quite different from majors with the same names in the U.S., so that the results would not directly generalize to the U.S.
} 
The third hypothesis is the hypothesis of Sacerdote and Glaeser (2001) that education increases the value people see in social networking, which should raise religious attendance more than religious belief. Although these three hypotheses are primarily about the effects of education overall, each of them has some relevance to the effects of different majors to the extent majors differ in the extent to which they attack religion as superstition, develop a capacity for abstraction helpful for religion or impress upon students the value of social networking.

Stark, Laurence Iannacone, and Roger Finke (1996) and Iannacone, Stark and Finke (1998) argue against the Science Drives Out Superstition Hypothesis, which they argue gained force more from the anti-clerical agenda of late $19^{\text {th }}$ and early $20^{\text {th }}$ century scholars than from solid evidence. In a compact and important argument, Stark, Iannacone and Finke (1996) argue in particular that (i) rates of religious belief, at least in America, have held up well in the face of scientific advances, (ii) educational attainment and religiosity are positively correlated, (iii) scientists, professors and graduate students are only a few percentage points lower in religiosity than the overall population, and (iv) "faculty and students in the 'hard' sciences are on average more [italics in original] religious, not less, than their 'soft' science and humanities counterparts." They cite data from the Carnegie Commission's 1969 Survey of American Academics showing that $60 \%$ of mathematicians, $55 \%$ of physical scientists and life scientists, 49 to $51 \%$ of Economists, Political Scientists and Sociologists, but only $33 \%$ of Psychologists and $29 \%$ of Anthropologists described themselves as religious. Data on religious attendance show the same pattern of relative irreligion on the part of Psychologists and Anthropologists, with the more macro-social scientists, then the life scientists and physical scientists, and finally mathematicians were progressively more religious. ${ }^{5}$ Thus, it is important for us to entertain hypotheses about the effects of education on religiosity relevant to the Social Sciences - and the Humanities - as well as the natural sciences. Mankiw's Capacity for Abstraction Hypothesis and Sacerdote and Glaser's Social Networking Hypothesis have not been addressed as thoroughly in the literature.

The Formative Role of the College Experience. Our own set of hypotheses begins with our view that education has an ideational dimension. Although there are multiple avenues through which school attendance and achievement can influence human behaviors and values, one of the most important is the role of education as a conduit distributing, legitimizing, and endorsing new ideas and views of the world. After all, schools are explicitly designed to provide students new information about the world - including new theories and ways of viewing the world. Schools are also explicitly designed to provide students literacy, numeracy, and other cognitive skills that permit them to engage the larger world fully after they complete their formal education. Thus, compared to the less educated, the well-educated have more access to new ideas and perspectives that can shape world views and beliefs later in life. Thus, it should not be surprising to find schools and educational attendance to be key nodes of spreading fundamental new ideas. Although some of the ideas inculcated by schools can be seen as affecting simple beliefs and patterns of cognitive processing, ${ }^{6}$ fundamental ideas about what is most important in life inevitably affect preferences themselves.

A fair amount of evidence in the social science literature suggests that the young adult years are particularly impressionable. For example, Scott and Schuman (1989) find that experiences and events during those years are often the most remembered throughout life. In addition, an extensive body of research suggests that attitudes and values during the young adult years are particularly volatile, while during the later years attitudes and values have crystallized and are more stable (Alwin 1994; Thornton and Binstock 2001). College in particular appears to lead to a shifting of values, followed by greater stability in the years following college (Jennings 1993). In fact, the

\footnotetext{
${ }^{5}$ Data on self-described active opposition to religion show $19 \%$ and $21 \%$ rates on the part of Anthropologists and Psychologists, while all the other groups of scientists we have mentioned are in the 10 to $12 \%$ range for active opposition to religion.

${ }^{6}$ Although stylized economic models often represent the cognitive processing of available information as costless and perfectly accurate, imperfect cognitive processing and variations in effectiveness of cognitive processing have been an important theme in economics. See Daniel Benjamin, Kimball and Robert Willis (2006) for a discussion of this literature.
} 
dislocation of attitudes and values associated with college attendance are often reported as large enough to be stressful (Jennings 1993).

The explicit role of education, including the type of college and curriculum, has also received attention in the social science literature. Although we do not consider the type of college attended in this paper, we note that Guimond (1999) looks at the effects of attending a military college while Newcomb and his colleagues study the effects of attending an innovative elite college (Newcomb 1943; Newcomb et al. 1967; Alwin et al. 1991). Crosssectionally, an extensive literature documents important correlations between the major of a student and that student's religiosity. A consistent theme in the literature is that students majoring in business, management, accounting, and related disciplines place more emphasis on occupational success, the making of money, and the goals of industry (Easterlin 1995; Easterlin and Crimmins 1991; Leppel et al. 2001; Duff and Cotgrove 1982; Jennings 1993). The research of Easterlin and Crimmins (1991; also see Easterlin 1995) even suggests that trends in the college majors chosen by students in the 1970s and 1980s are directly related to the values students place on economic success. Business majors also tend to place less emphasis than do other majors on freedom, empathy, protecting the environment, finding personal fulfillment, performing community service, fostering equality, and correcting social injustices (Shiarella and McCarthy 2000; Sidanius et al. 2003; Jennings 1993; Bécares and Turner 2004). In fact, the reputation of business majors for placing emphasis on material success and downplaying social and environmental responsibilities has led some business colleges to explicitly introduce social responsibility and community service into their curriculums (Zlotkowski 1996; Hogner 1996; Kolenko et al. 1996; Ridener 1999).

Majors in the social sciences and humanities have been identified as having distinctive forms of religiosity. For example, they tend to place more emphasis on the environment, an attribute shared by those majoring in biology (Hodgkinson and Innes 2001). They also tend to place more emphasis on egalitarianism, tolerance, and freedom and less emphasis on business (Sidanius et al. 2003; Jennings 1993; Duff and Cotgrove 1982; Biddle et al. 1990). Psychology and nursing students have been reported to be higher than others on empathy (Bécares and Turner 2004).

\section{A “Cultural Engineering" Assessment of Science, Developmentalism and Postmodernism}

As mentioned above, we identify three powerful streams of thought that are relevant for the effects of college majors on religious beliefs and commitment: Science, Developmentalism, and Postmodernism. We make no claim that these three perspectives or approaches are exhaustive of the major new ideas or that they are mutually exclusive. Instead, we identify them as important unifying themes that are distributed unevenly across the major disciplines of academia and have important implications for religious ideas and beliefs. At this point, we attempt an a priori "cultural engineering" assessment of each of these three streams of thought and their likely interactions with religiosity.

Science: There are several elements of the scientific approach that bring science into a tension with religious dogma and authority. Among the most important is the creation of a separate structure of authority and epistemology. Science provides a methodology that relies on the powers of human observation, experimentation, and the correction of old ideas and perspectives with new information. In principle at least, every proposition of science is open to examination and reappraisal, making it possible for the emergence of new perspectives and understanding. This approach to knowledge is also, in principal, free and universal in that everyone has the ability to observe and test ideas and conclusions. This provides science a methodology and approach that stands in contrast to a methodology relying on religious authority and revelation. 
Over the course of the past several centuries, science has created an extensive institution of personnel, books, journals, and legitimacy that serves as an alternative authority structure to religious institutions. Just as some people listen to religious authorities for knowledge and guidance, some listen to scientific authorities for knowledge and guidance. And, to the extent that the new institution of science brings information and perspectives that conflict with those of religion, it has the potential of undermining the perceived authority and relevance of religious institutions.

Science has, of course, been the source of many new perspectives that have conflicted with many long-cherished views of Western religion. Among the most important of these are the vastness of the universe and its implications for the place of the earth in the cosmos. This is the current extension of the Copernican shift from the earth at the center of the universe to the sun at the center. Now, even our solar system is viewed as one among many in the cosmos, making the earth seem like an insignificant speck in the universe. This raises many well-known questions and problems for Judeo-Christian religions, including the following: 1) the contrast of this picture with the one historically taught by Western religions; 2) the implications of this view for the relevance of such a small and insignificant planet for the God of the whole universe; and 3) why events on this small planet would have significance throughout the cosmos.

Specific scientific theories of the universe and life on earth - including the big bang theory and biological evolution - provide key alternatives to God as the answer to the questions of "where did we come from" and "why are we here". Modern cosmology (the big bang and theories about its antecedents) and evolution provide the only widely recognized way to answer these fundamental questions without having a faith in God. As a result, many religions have bitterly attacked these ideas of science and staked a lot of prestige on evolution being false. Learning about modern cosmology and evolution and coming to believe in them are likely to be particularly problematic for those who come from religions that have staked much prestige on evolution being false. But regardless of one's religious traditions, modern cosmology and evolution give a person the option of disbelieving in God.

Besides providing an answer to questions about the origin of humans, evolution is beginning to offer answers to the meaning of humanity and the ways humans behave and interact, with some of these answers being problematic for historical religious teachings in the Western world. One of the most important elements here is the equation of humans with animals. The theory of evolution provides an alternative view to the idea that people are a little lower than the angels or made in the image of God by suggesting that we are closely related to the apes and may indeed have apes as ancestors. This viewpoint - and the growing understanding of the marvelous abilities of the animals - also reduces the perceived uniqueness of human beings. It removes us from the center of the biosphere in much the same way that Copernicus removed us from the center of the universe.

Also relevant here is the naturalistic equation of mind and brain. As a matter of course, neuroscientists now think of mind and brain as two sides of the same coin. The reduction of mind to electro-chemical reactions is reinforced by the power of pharmacology in treating mental illnesses. The biggest challenge to religion here is the research program of explaining religious experience as a brain phenomenon rather than as a connection with deity. This is immensely powerful in dismissing religious experiences as genuine reflections of the supernatural. Also, the tight relationship between the brain and mind calls into question many religious pictures of an immortal soul separate from the body. Another related, but perhaps more subtle, challenge to religion is that of psychology, as both talk therapy and pharmacology represent direct substitutes for religion as a path to happiness.

Finally, the reductionism of science presents a challenge to religious mysteries. Perhaps the ultimate reductionism of science comes in the emphasis upon the smallest constituents of matter and energy, with physicists suggesting that the universe is ultimately composed of innumerable mysterious, and for the common person, such ultimately 
unfathomable and unbelievably small things as quarks, leptons, force particles, bosons, and strings. Everything is viewed as made of a small number of basic participles obeying a small number of equations. In those equations, there is no obvious place for the spirit or God to come into the picture.

Developmentalism: A second stream of thought that poses a challenge to religious commitment and participation is developmentalism. The roots of developmentalism lie in the perspectives of the ancient Greeks and Romans and permeated the teachings of early leaders of the Christian church. Then, as Arland Thornton (2005) documents, the Enlightenment of the 1600s and 1700s used these ideas to head in new directions, that had profound implications for family life both in the Western world and elsewhere around the world. Developmentalism also had profound implications for religion.

Oversimplifying, Developmentalism is based on a simple analogy between the development and progress of societies to the development of individuals across their individual life spans. Just as individual human beings develop from birth through childhood and adolescence to young adulthood, middle age, old age, and ultimately death, human societies develop through similar life cycle stages. During the Enlightenment, old age and decline were eliminated from the equation and replaced by eternal advancement and progress.

Perhaps the most important creation of Developmental thinking was a narrative of progress. In this story, development, or progress, was viewed as starting from a state similar to that of the societies outside of Europe that were most different from Western Europe and then moving step by step through increasingly advanced stages of civilization until reaching the perceived pinnacle of advancement in Western Europe. Society was believed to have progressed from having the kinds of economic, social, political, religious, and familial systems existing outside the West to those in the West.

Perhaps even more importantly for our purposes, as Thornton (2005) argues at length, this story of human history provided a framework for evaluating human institutions and a roadmap for achieving future progress. On the evaluative side, things associated with the contemporary West received the imprimatur of history as being progressive, modern, advanced, enlightened, and developed. They were good and to be emulated. And, in opposition, things outside the West - especially those very dissimilar from the West-were labeled as traditional, undeveloped, backward, uncivilized, or worse. They were bad, inhibitors of the good life, and to be eliminated.

Among the elements of life in the non-Western world that came to be associated with backwardness and the poor life were numerous family dimensions such as extended households, young age at marriage, marriages arranged by parents, high levels of parental authority, great inequality, and group solidarity. On the other hand, Western family systems were labeled as good and progressive; these included such aspects as nuclear households, an older age at marriage, high autonomy of the young, a marriage system based on individual courtship and consent, higher levels of equality, and individualism. Similarly, agriculture and family modes of production were seen as backward and less valued while industry, urban living, and non-family modes of production were seen as advanced and good. In the political arena freedom, equality, and democracy were not only believed to symbolize progress but to be mechanisms for reaching the good life. Education also became associated with the good, both as an end and as a means. In addition, Western religion was seen as part of the march of civilization, a theme that we will return to below.

Interestingly, as Thornton documents, in the Western world, this developmental framework became a blueprint for future progress. In essence, the past history of development was projected into the future. Just as progress in the past had moved society from agriculture and family modes of production to industry, cities, and non-family modes of production, future progress would be brought by even less agricultural and rural life and more emphasis upon non-family production. Just as past progress had brought less communalism and less emphasis on institutions and 
authority, future progress would also bring more individualism and less emphasis on external authority. The longterm evolution of society from having a high degree of control and individual inequality would continue into the future, with freedom and equality becoming key elements of future progress. Similarly, it was believed that extended households, parental authority, arranged marriages, and the wide influence of the family would decline in the future as they had in the past.

Most importantly for our purposes is the fact that religion and religious institutions eventually became tagged with the labels of backwardness and as opponents of progress. This occurred despite the fact that Western religion was seen by many during the early years of the Enlightenment as a powerful force in bringing the Western world to its perceived pinnacle of progress. It is likely that this perceived movement of Western religion from the engine of progress to the brakeman of progress was associated with the continuing commitment of Western religion to many of the historical patterns of social, religious, and family life.

For example, religious groups in the West have actively resisted many of the new forms of freedom and equality that grew out of the Enlightenment. One example is an emphasis on religious authority rather than individual decision making. Another is Western religion's long opposition to reproductive freedoms, including the right to contraception and abortion. Also relevant here is the emphasis upon sexual abstinence outside of marriage, in contrast to the revolution in sexual freedom. Another is the historical opposition of religious institutions to divorce and the freedom to remarry. More recently, many religious groups have opposed the freedom of homosexuals to enjoy the rights and privileges of marriage. And, on the equality front, religious groups have come to be perceived as defending old orders of hierarchy and inequality rather than equality. And, of course, this association of religion with backwardness is strengthened by religious opposition to many of the new discoveries of science that are themselves labeled as advancement or progress.

We believe that this perceived association of religion with the forces of backwardness in opposition to the forces of progress and advancement has substantial implications for the attractiveness of religion in today's world. To the extent that the belief in progress and the perceived association of religion with the forces holding back progress are widespread today, the authority of religion will be substantially undermined, as will the commitment and participation of individuals in religious activities. We believe that these perceptions and beliefs are widespread today, with important ramifications for religious practices and commitments. Furthermore, it is clear that educational institutions can be an important avenue for the distribution of such perceptions and beliefs.

Postmodernism. An essential element of postmodernism is relativism, the rejection of absolute or universal standards or criteria. Knowledge and truth are seen from a Postmodern perspective as a construct of socio-cultural conditions rather than an absolute dictum from God or pronouncement from religious authorities. It is thus a function of criteria specific to local cultures, historical periods, or sociopolitical interests. As a result, both truth and morality are seen as varying across history, geography, and culture rather than being absolute for all times, places, and peoples.

This relativism of Postmodernism is corrosive of religious belief and activity in at least two ways. First, many religions teach that there is an absolute truth or knowledge emanating from God. The shifting of knowledge and truth from God onto the faith community leaves little room for absolutes and the definitive pronouncements of religious authorities. A second way that relativism stands in contrast to religious beliefs is that as compared to religious approaches, there is not one pathway to truth and knowledge - for example Christianity's teaching of Jesus being "the way, the truth, the life", and the only way to experience God. The relativistic ways of postmodernism, in contrast, suggest that there are many ways to truth, goodness, knowledge, and morality. Although religions may teach that specific practices are good and right and adhering to these practices makes an 
individual moral and good, a Postmodern relativistic perspective suggests that these practices are components of a system of localized rather than universal knowledge and truth.

Postmodernism is associated with epistemological doubt - the idea that knowledge and certainty are extremely difficult to attain. This position suggests that instead of knowledge being given absolutely, it is constructed by human beings through their sometimes faulty capacities of observation and reasoning. This epistemological doubt comes into conflict with religious beliefs suggesting the existence of absolute knowledge, truth, and authority rooted in God's revelation and teachings to human beings.

Another element of Postmodernism is its emphasis upon the place of social and political power in constructing the truth. Here Postmodernism suggests that what counts as truth is defined at least in part in terms of social and political power. That is, social and political power can give authorities the means to define what is true and enforce that definition on others with alternative viewpoints. This line of argument can be especially powerful when it is applied to religion and the church itself, an institution that has long had extensive power in the Western world.

A similar line of reasoning argues for the importance of power relationships in defining morality: what is right and appropriate. Just as political power can be seen as a source for defining truth, it can be seen as a source for defining what is right. In this way, the moral is what those in power say it is. Again, this kind of reasoning can be especially corrosive when applied to religion because it suggests that the long-standing historical power of the church has historically defined views of morality — with no higher basis than raw power.

The postmodern approach to human affairs has become particularly widespread in the academic world in recent decades. It has materially affected many disciplines, with old institutions and authority structures deconstructed in order to understand their social origins and use of power in influencing human conceptions of truth and morality. It is our hypothesis that this relativistic and questioning approach learned in college can have a particularly powerful corrosive effect on religious commitment and participation.

Postmodernism is a much more recent stream of thought than Scientism and Developmentalism. This may enhance Postmodernism's effect on religiosity. Religious institutions have had a longer time to figure out how to ameliorate any negative impact of Science and Developmentalism on religiosity. The basic strategies are to either harmonize Science and Developmentalism with religion, or to fight them. In either case, experience with these streams of thought could improve the ability of religious institutions to avoid negative effects on religiosity. Since Postmodernism arose more recently, religious institutions have not had as much time to figure out how to deal with it.

\section{Previous Literature on the Effects of College Major}

In explaining the correlation between college major and religiosity, the most fundamental issue is the direction of the causality - from college major to religiosity or from religiosity to college major. This issue is well recognized in the literature (Jennings 1993; Guimond 1999; Sidanius et al. 2003; Duff and Cotgrove 1982; Thistlethwaite 1973; Biddle et al. 1990). Unfortunately, purely cross-sectional research cannot directly address the direction of causality.

There are some studies using complex panel data that have attempted to evaluate the reciprocal causation between college major and attitudes and values (Jennings 1993; Thistlethwaite 1973; Bécares and Turner 2004; Ethington and Wolfle 1988; Duff and Cotgrove 1982; Sidanius et al. 2003; Biddle et al. 1990; Guimond 1999). That research is uniform in documenting the existence of correlations between major and attitudes and values very early in the 
college experience (Jennings 1993; Duff and Cotgrove 1982; Thistlethwaite 1973; Sidanius et al. 2003; Biddle et al. 1990). In fact, there is some evidence suggesting that such correlations have their roots back in high school or even earlier (Jennings 1993; Ethington and Wolfle 1988). These early correlations are often interpreted as reflecting selection into majors based on attitudes and values. However, this conclusion is speculative as it ignores the actual causal connections during the elementary and secondary school years that produced the early college correlation.

There is also considerable evidence suggesting that the college experience exposes people to new ideas and peer groups and in doing so changes attitudes and values. For example, Jennings (1993) and Guimond (1999) have observed changes during and after college that they attribute to such socialization mechanisms.

However, other researchers looking at the influence of college major on subsequent attitudes and values report little causal influence in this direction. (Duff and Cotgrove 1982; Thistlethwaite 1973; Sidanius et al. 2003 Biddle et al. 1990). This has led some to the suggestion that the major thrust of the causal mechanisms producing the correlation is the selectivity of college major on attitudes and values. If this interpretation were correct, attitudes and values would be the active causal force (rather than college major) producing the correlation between major and attitudes.

This paper contributes to this debate by examining the reciprocal causation between college experiences and religiosity using a unique data set that follows young adults from the senior year in high school through the young adult years. This data set permits us to evaluate changes in both majors and religiosity during the college years.

As noted earlier, one of our two central hypotheses is that college attendance in general and the experience in a specific major will influence religiosity. We test this hypothesis by relating college major to subsequent religiosity. By treating "No College" as if it were a major, we can see the effects of college versus no college as well as the effects of specific majors.

We believe that college majors could influence individual religiosity in several ways (Guimond 1999). One important mechanism is through the information and ideas disseminated by professors and the scholarly literature students come into contact with. That is, the formal curriculum could influence the religiosity of students. A second mechanism is through informal peer relationships. Here we suggest that the student peers in the various majors can vary dramatically and that new students entering majors can learn and assimilate the attitudes and beliefs of their disciplinary peers.

Although we believe that the comparison of the religiosity of people following different courses of instruction will provide useful information on the effects of college attendance and curriculum, we also recognize that these crossmajor comparisons will provide an underestimate of the overall influence of the college experience. The reason is that virtually all college students are exposed to some extent to the forces of Science, Developmentalism, and Postmodernism. This is because almost all colleges have a common core curriculum that everyone takes. It is also fairly common to have distribution requirements explicitly intended to ensure a broad education in many different disciplinary traditions. Campus-wide speakers draw students from a wide range of majors. Dormitories, extracurricular activities, and innumerable peer interactions informally distribute what is learned in one area across the entire campus. So, in practice, this mixing would make the comparison of results across majors less marked. However, this mixing should not totally remove the influence of college majors on religiosity.

Our second central hypothesis is that there are many ways in which students are selected on the basis of their attitudes and values into various college majors. In America students are not randomly assigned to a major, but choose it on the basis of their goals and interests. Students also probably have some ideas about the extent to which the underlying philosophies and approaches of a major and the occupations they lead to match their own 
values and beliefs. Of course, the experiences at college may provide substantial additional information along these lines, with some students who initially decide upon a major becoming disillusioned and deciding to change their major in mid-stream. We test this hypothesis by relating current religiosity to subsequent decisions about college majors.

\section{Data and Methods}

Our investigation of the influence of college attendance and program of study will rely on data from the Monitoring the Future Study. This is a very rich and important data set that has been collected by researchers at the University of Michigan from 1975 to the present. The Monitoring the Future Study has been funded under a series of competing research grants from the National Institute on Drug Abuse, a part of the National Institutes of Health. It is the primary source of national data for documenting trends in drug use and evaluating the causes and consequences of the use of various chemicals in young adulthood.

Each year since 1975 MTF has interviewed approximately 16,000 high school seniors in the United States using a multistage sampling strategy (Bachman et al. 2000). Each cohort is nationally representative of high school seniors in the coterminous United States, and includes students that attend both public and private schools. Beginning in 1976 and every year thereafter, a subset of approximately 2400 students has been drawn from the high school senior sample using stratified random sampling procedures and asked to participate in follow-up studies. These mail-in follow-up surveys update demographic information and replicate attitudinal and behavioral measures originally collected during the high school contact. The first reinterview for one-half of the sample takes place one year post-high school and the first reinterview for the remaining 1200 students occurs two years after high school graduation. The entire subset is then reinterviewed every two years starting from the initial one or two year post-high school contact. This every-other-year strategy continues until respondents reach 35 years of age; thereafter individuals are surveyed once every 5 years. $^{7}$

One of the important features of Monitoring the Future is that the study collects a great deal of information other than that relating directly to drug usage. The study collects a broad array of information about many dimensions of values and behavior concerning school, employment, family, politics and community. This information is not only collected during the senior year of high school, but — for a subset of the sample - every other year after senior high.

--Table 1 here--

Most importantly for our purposes, Monitoring the Future collects extensive information about religion and education - both at the initial data collection and with each of the follow-up surveys. For example, in the domain of religion, the data set includes several measures of religious commitment and participation. The high school seniors are asked at the base year and at each follow-up to report the frequency with which they attend religious services. They may respond that they never attend religious services, do so rarely, once or twice a month, or about once a week or more. The first row of Table 1 shows that, on average, there is a decline in attendance of almost $12 \%$ over the 5-6 years after high school. Respondents are also asked to report the importance of religion in their lives. Respondents may indicate that religion is not important, a little important, pretty important, or very important to them. Interestingly students report a slight increase in importance over the 5-6 years after high

${ }^{7}$ The baseline interview takes place at the high school, and follow-up interviews are done primarily via mail or occasionally by telephone. Every interview contains an identical set of core demographic measures asked of all sample respondents. In addition, at the baseline interview each respondent is assigned one of six sets of attitudinal measures that are repeated throughout all years of study participation. 
school. ${ }^{8}$ Finally, detailed information on the denominational preference of the respondents is collected during the initial base year interview. Eighteen response categories are provided for denominational preference. ${ }^{9}$

At each follow-up survey, MTF asked respondents to categorize their current school status into the following 12 areas: none (did not attend college), office and clerical, vocational and technical, biological sciences, business, education, engineering, humanities and fine arts, physical sciences and mathematics, social sciences, other academic fields, and academic, but undecided about which major field. For the purposes of our analyses we combine the office/clerical and vocational/technical into one Vocational group and we also combine the other academic and undecided majors to make a total of 10 college major categories.

Our objective is to investigate both the influence of college major on religiosity and the effects of religiosity on choice of college major. We turn first to our approach in analyzing the effects of college major on religiosity and then to our approach in examining the effects of religiosity on the choice of major.

\section{The Effects of College Major on Religiosity}

--Figure 1 here--

As mentioned above, our basic strategy to identify the effects of college major on religiosity is to follow individuals across time and see how changes in religiosity and values are associated with school enrollment and choice of major. Latent growth curve models allow separate trajectories over time using repeated measures (Singer and Willet 2003; Bollen and Curran 2004). We model change for each individual beginning with their religiosity at their senior year in high school (Year 0) and ending at the third follow-up interview (Year 5 or Year 6). Figure one provides a visual representation of our model. Two latent factors, the intercept $(\alpha)$ and the slope $(\beta)$, represent the growth over time. Thus it estimates the group level (fixed) means and the random (individual) effects as well. Controls are used to predict the growth curve, while college major provides time varying adjustments to the scores, after removing the growth curve. Thus for individual $i$ at wave $w$, their religiosity score is determined by the following equation for $w=0,1,2,3$ :

\footnotetext{
${ }^{8}$ The survey also asks respondents to indicate whether they contribute money to religious organizations or are likely to do so in the future. In addition, they are asked to report the degree to which they believe that the influence and power of church in our society is appropriate. At each survey, respondents indicate whether they think that religious organizations should have more influence, less influence, or about the same influence as these organizations have now. We discuss results based on these variables after the main results.

${ }^{9}$ Our analyses also controlled for the year of initial survey using dummy variables (5 year cohorts with the oldest group -- those originally interviewed from 1976 through 1980 -- as the omitted reference group), region (Northeast, South, and West, with Midwest as the reference group), gender (female), race (black or African-American), parental education (in years), and religion, (Catholic, conservative Protestant, unaffiliated, other/none, with mainstream Protestant as the omitted reference group).
}

We restricted our sample to respondents who had their first recontact interview no later than two years post high school graduation, and a minimum of three sequential follow-up interviews. In each of the six separate religiosity analyses the sample was also restricted to those supplying four full sets, (i.e. no missing data), of the relevant religiosity indicator-at the high school contact as well as during the next three follow-up surveys. In addition, respondents were required to provide valid post-secondary education status data at the first followup in order to remain eligible for these analyses. With these restrictions, the sample we use in our two main analyses includes approximately 26,200 individuals originally interviewed between 1976 and 1995. The remaining four analyses included approximately 4900 individuals in each. 


$$
\begin{aligned}
& R_{i w}=\alpha_{i}+w \beta_{i}+M_{i, w-1}^{\prime} \gamma_{w}+\varepsilon_{i w} \\
& \alpha_{i}=Z^{\prime} \delta+\eta_{i} \\
& \beta_{i}=Z^{\prime} \zeta+\xi_{i} \\
& \gamma_{0}=0 \\
& \gamma_{1}=0,
\end{aligned}
$$

Where $R_{i w}$ is a measure of religiosity for individual $i$ at wave $w, \alpha_{i}$ and $\beta_{i}$ are the intercept and slope for the individual's latent growth curve, $M_{i, w-1}^{\prime}$ is a transposed vector of dummy variables for the various majors, $\gamma_{2}$ is a coefficient for the effect of major on religiosity by wave 2 (based on wave 1 major), $\gamma_{3}$ is a coefficient for the cumulative effect of major on religiosity by wave 3 (based on wave 2 major), $Z$ ' is a transposed vector of timeinvariant controls, and $\varepsilon_{i w}, \eta_{i}$ and $\xi_{i}$ are error terms. Based on the configuration noted above the growth curve is constrained to be a linear growth. ${ }^{10}$ The effect of the individual's previous college major $\left(\mathrm{M}_{(w-1) w}\right)$ is the focus of our study. The interpretation of this effect is therefore, the cumulative predictive power of college major in wave $w-1$ on religiosity at wave $w$, net of the underlying change of religiosity as predicted by the time-invariant controls.

\section{The Effects of Religiosity on College Major}

We also believe that religiosity is likely to have important effects on the initial choice of college major. However, these effects are very difficult to disentangle from the effects of other forces that influence both religiosity and college major. For example, it is possible that initial college majors are influenced heavily by parental religiosity, which is not measured in our data set. Because these parental attitudes are likely to be correlated with child religiosity, a correlation between major and initial religiosity could arise even in the extreme case in which the child's religiosity had no causal effect on the child's college major. Although it is not possible to escape such issues entirely, we focus on our respondents' changes in majors after an initial choice of a major, which we hope will be more indicative of the college student's own preferences than the initial choice of major. For one thing, given the hassle involved, a college student is only likely to change a major if the desire to do so is reasonably strong. Second, to the extent parents are a big influence on choice of major, one can presume their preferences are imprinted on the initial major, so any change away from that is more likely to reflect the child's own preferences. Third, by definition, a student changes majors at a later age than the age at which the initial major was chosen; that additional age will typically put more psychological distance between the student and parental authority. Given the limitations of our data set, this focus on changes in major is the cleanest test possible for the effect of the student's own religiosity on his or her college major.

Given the strong tendency to just stay put, we break our analysis of changes in major into two pieces: the analysis of the decision to leave one's initial major and the analysis of which major to choose instead. Intuitively, one can think of this as analyzing the attraction or repulsion of the initial major and the attraction or repulsion of alternative majors. That is, in our analysis, we look first at how a student's religiosity is related to variations in retention in different initial majors and then at how religiosity is related to the alternative major chosen. Econometrically, we use standard logit models to analyze first retention in initial majors and then sorting into a new major of those who change majors.

\section{Measures of Religiosity}

\footnotetext{
${ }^{10}$ A curvilinear relationship was examined, but did not fit the data nearly as well as the linear model presented in this paper.
} 
For clarity of interpretation, in all of our statistical analyses, we do separate analyses for each measure of religiosity. We focus on the two measures that are available for all respondents: importance of religion, as measured by the answer to "How important is religion in your life [not important, a little important, pretty important, very important]" and religious attendance, as measured by the question "How often do you attend religious services? [never, rarely, once or twice a month, about once a week or more]. We use a simple linear measure (1-4) of the response categories offered, thus implicitly assuming the differences between the two neighboring categories represent an equally important gap. We think it unlikely that any of the results depend in an important way on this shortcut ${ }^{11}$.

\section{RESULTS}

--Table 2 here--

Table 2 displays the results of the latent growth curve regressions for the effect of college major on religiosity. With the underlying growth rate of religiosity controlled in the model, the coefficient on college major shows how far religiosity departs from the trend that is estimated the individual would follow if he or she pursued a business major. The major is lagged by one wave (two years) to help ensure that we are focusing on the effect of college major on religiosity as distinct from the reverse effect of religiosity on college major addressed below.

It is important to clarify two dimensions of the interpretation of the coefficients in Table 2 as effects of college major on religiosity. First, assuming the statistical analysis is appropriate, the estimates will be a treatment effect on the treated. In the case of college major, the treated are likely to be especially susceptible to the treatment that the major represents. The effects might be quite different if a student were forced into a major. Second, as alluded to above, a major must be thought of broadly as all of the ways the college experience will be different for those in one major rather than another, including systematic differences across majors in the types of peers a student associates with, systematic differences in non-assigned reading, systematic differences in outside cultural and volunteer activities, systematic differences in types of summer and term-time jobs, and so on. It is useful to think of this penumbra of a major as a kind of implicit curriculum that complements the explicit curriculum of a major. Finally, in our interpretations of all of the tables below, we will discuss estimates that are "statistically significant" at the $5 \%$ or $10 \%$ level as individual estimates even though we are estimating many parameters. We are confident that readers will find this exercise useful in updating their priors.

The most important news in Table 2 is that college major seems to have significant effects on religiosity. Being a Humanities or a Social Science major (compared to a Business major) has a statistically significant negative effect on religious attendance and self-assessed importance of religion in one's life. Social Science seems to have slightly stronger effects. All of the negative effects of both of these majors appear to become more negative over time, with the effect of being a Social Science major on religious importance almost doubling. Because we consider both the Humanities and many of the Social Sciences particularly strongly imbued with Postmodernism, we take this as evidence for a negative effect of Postmodernism on religiosity.

Another important result is that the Biological Sciences and the Physical Sciences do not seem to be related to religious attendance. However, the Physical Sciences do appear to be negatively related to importance of religion, at the $5.5 \%$ level of significance early on and the $3.6 \%$ level of significance later on. Since we expect both of these majors to have a strong Science focus, this suggests at best a weak effect of Science on religiosity.

\footnotetext{
${ }^{11}$ Some initial explorations into using statistical methods to account for the non-continuous nature of the religiosity measure have not shown substantially different results.
} 
Education majors provided the most surprising result: majoring in education appears to increase religiosity. This appears especially true for religious attendance, showing the largest coefficient of any in the first two columns of Table 2. The effects of Education on religious attendance and importance appear to increase in strength over time.

As compared to a Business major, Other/Undecided has no significant effect on importance of religion, but appears to have a negative effect on religious attendance. We do not make too much of No College showing a positive effect on importance of religion early on at the $10 \%$ level of significance given that the point estimate shows no effect later on. However, the negative effect of No College on religious attendance is clear. Finally, Engineering and Vocational majors seem to be similar to Business majors for both religiosity measures.

\section{Effects of Religiosity on Stability of College Majors}

In this section we look for a causal arrow in the opposite direction - that is, we look for an effect of religiosity on the choice of college major. As mentioned above, we do so in terms of two decision-stages. First we study the extent to which religiosity affects staying in a major. Second, we study the extent to which religiosity influences the choice of new majors among those who do change majors.

Table 3 indicates how retention in a particular major between the first and third follow-up interviews depends on religiosity at the first follow-up interview. We estimate the effect of religiosity and controls on retention in each major separately for each initial major and each measure of religiosity. We interpret the coefficients on the religiosity measures in Table 3 as the causal effect of a congenial match or uncomfortable mismatch between a student's level of religiosity and the attitudes common in the major or other characteristics of the major. ${ }^{12}$ The key identifying assumption is that the list of controls includes all variables that are correlated with both religiosity and with changes of major. Note that we do not need to assume we have included all of the variables that are correlated with the initial choice of major, since we are focusing on changes in major.

Both importance of religion and religious attendance are related to students who were not in college at the first follow-up interview leaving their non-attendance status to go to college by the third follow-up interview. The effects are large as well as significant. A change in religious attendance by one point on the four point scale raises the odds-ratio of going to college by $14 \%$. A change in importance of religion by one point on the four point scale raises the odds-ratio of going to college by $8 \%$. It is easy to see how religious attendance could lead to higher college enrollment simply through the encouragement of college enrollment by fellow churchgoers. (One might call this the "Nagging Theory.") On that view of how the causation works, importance of religion could be associated with higher college enrollment simply because it is associated with higher religious attendance.

The data also suggest that both religious importance and religious attendance influence education majors to stay put rather than to migrate to another major, although the effect for attendance is statistically significant at only the

\footnotetext{
${ }^{12}$ Because of the measurement error, we expect the coefficients on religiosity to be biased downward but still expect them to show the direction of effects (if religiosity is not too highly correlated with the controls). Because we have estimated the size of the measurement error for the two measures of religiosity in previous work, we could make a correction for the measurement error that would undo the bias, but we do not think this would qualitatively affect the results. Kimball, Sahm and Shapiro (2008) show in a different context how this kind of correction can be done, but also illustrate the modest effect such a correction often has on t-ratios. This note applies equally to Table 4, discussed below. For the purposes of this regression, it makes sense to interpret "religiosity" as a package of attributes that remain correlated with importance of religion or religious attendance after controlling for the other variables in the regression. On this interpretation, a positive coefficient indicates that a high value of religiosity is correlated with attitudes that help a student to stay in the major; a negative coefficient indicates that a high value of religiosity is correlated with attitudes that tend to cause a student to quit the major.
} 
$10 \%$ level. Further, the estimated effects are substantial, with each unit of attendance and importance increasing the odds-ratio for stying in education by $14 \%$ and $24 \%$ respectively.

The only other significant effect for importance of religion on stability in major is an association with moving out of the Other/Undecided category. Given this association, it is curious that religious attendance shows a smaller, statistically insignificant association with moving out of the Other/Undecided category.

Religious attendance is positively associated at the $10 \%$ level of significance with staying in the Social Sciences, Biological Sciences and Business majors. All of the significant effects are large in magnitude, with one point on the religiosity scale changing the odds-ratio of staying in a major by at least $9 \%$ (Business) and at most $13 \%$ (Biological Sciences). To speculate, the effect of religious attendance on staying in the these majors could reflect the influence of Developmentalist attitudes among churchgoers - attitudes distinct from the religious doctrine itself. The similarly significant and substantial negative effect of religious attendance on Vocational majors may be akin to the effect of religious attendance on getting individuals into college. In both cases, religious attendance encourages a shift toward a higher status path.

\section{Effects of Religiosity on Major Destinations}

If students leave one major, they need to switch into something else. Table 4 indicates the effects of religiosity on the new majors that switchers move into when they change majors. Since there is an adding-up constraint that students must switch to something, we must again use the Business majors as a reference group. That is, we look at the likelihood of choosing a particular major compared to the likelihood of choosing a Business major. Since "No College" means never having attended college, students cannot switch into this category. Since we view college major as the type of college education rather than the quantity, we count a student as keeping the same major when he or she drops out of college.

We interpret the coefficient of religiosity in this regression as the causal effect of religiosity on what new major is chosen, conditional on having switched out of an earlier major. The key identifying assumption is that we have managed to include as controls all variables that have a strong correlation with both religiosity and changes of major in our regression, other than the constellation of attitudes that we would be happy to include as part of the package "religiosity." Again, we do not need to assume we have included all of the variables that are correlated with the initial choice of major, since we are focusing on changes in major.

Both importance of religion and religious attendance significantly predict that students will switch into Education. For religious attendance, one point on the four point scale is associated with an $11.0 \%$ higher odds-ratio of switching into Education as opposed to Business. For importance of religion, one point on the four point scale is associated with a $17.4 \%$ higher odds-ratio of switching into Education as opposed to Business.

Religious importance also has a significant effect in choosing both the Humanities and Biology. For each one unit increase in importance, there is a $17.1 \%$ and $13.1 \%$ increase in the odds of switching to the Humanities or Biology, respectively, compared to choosing Business. At the $8.5 \%$ level of significance there is a $7.9 \%$ decrease in the odds of switching to the Social sciences compared to a Business major for each unit of religious attendance.

The Humanities provide a good example of what is learned by considering both causal directions. Although the Humanities seem to have a negative effect on religiosity, it seems based on tables 3 and 4 that highly religious people are not leaving faster than normal, and in fact more religious people tend to choose to enter the Humanities after leaving a previous major. 


\section{Secondary Indicators of Religiosity}

Monitoring the Future collects data on several variables that are not directly designed to measure religiosity, but may give some indication of a respondent's religious attitudes, mixed with what the variable was primarily intended to measure. We do not view the results for these variables as decisive in themselves, but we present them because they provide some degree of confirmation for the most important results above and provide some nuances for other results above. Monitoring the Future collected data for each of these secondary indicators of religiosity on only a fifth of the sample (a different fifth in each case). The reduced sample size means that some effects of a magnitude that would have been statistically significant for the primary religiosity measures will not be statistically significant for these secondary indicators. Also, as is also true above to a somewhat lesser extent, the sheer number of estimated coefficients makes it highly likely that some of the results below that are individually "statistically significant" occurred by chance.

Likelihood of Giving Money to a Church: In a sequence on attitudes toward charitable giving, respondents were asked "If you have at least an average income in the future, how likely is it that you will contribute money to the following organizations? If you have already contributed, mark the last circle only. Are you likely to contribute to ... Church or religious organizations [definitely not, probably not, don't know, probably will, definitely will, already have]?" The Humanities, Social Sciences, and Other UUndecided have similar, strong effects on reducing the likelihood of giving money to a religious organization (Table 2). Not entering college by at least the $4^{\text {th }}$ year also significantly lowers the self-reported likelihood of giving money. At the $10 \%$ level of significance, a higher likelihood of contributing to a church increases the odds of staying out of college and decreases the odds of staying in the Physical Sciences and Math (Table 3). The only other coefficients of interest that clear even the 10\% hurdle for statistical significance are in predicting switching major destinations (Table 4). Compared to those choosing Business majors, the higher the reported intention of religious giving, the more likely a respondent is to switch into Education and the less likely he or she is to switch into Physical Science or Math.

Churches doing a good job: A fifth of the sample was asked "How good or bad a job is being done for the country as a whole by churches and religious organizations [very poor, poor, fair, good, very good, no opinion]?" Analyzing this variable in exactly the same way we analyzed importance of religion and religious attendance, we found that the Humanities, Social Sciences, Biological Sciences, and Physical Science and Math had a significant negative effect on this measure of religiosity. Most of these affects appear large and significant. The causal arrow runs the other direction as well: for every one unit increase in this measure there was a $6.1 \%$ increase in the odds of entering college and a 39\% increase in the odds of staying in Engineering. Finally, compared to business majors, every unit increase in thinking the churches are doing a good job raises the odds of going into Education by $27.4 \%$ (at the $6.0 \%$ level of significance) and lowers the odds of switching to the Humanities by $27.7 \%$. Note the contrast between the negative effect of a positive view of organized religion on switching into the Humanities and the positive effect of the more individualistic "religion is important in my life" measure.

Leaving things up to God: Another fifth of the sample was asked: "If we just leave things to God, they will turn out for the best [disagree, mostly disagree, neither, mostly agree, agree]?" The answer to this question should reflect the respondent's perceived locus of control - the extent to which one can influence one's own fate-as well as degree of trust in God. Viewing this variable as primarily a locus of control variable makes sense of the results we find. People who stay out of college appear to increase in their trust in God, while people in the Sciences and Engineering actually experience large decreases, compared to business majors. Those who are more ready to leave things to God are more likely to stay in the No College and the Other/Undecided categories. A one point higher assent to the statement above raises the log odds ratio of staying out of college by $9.5 \%$ and raises the log odds ratio of staying in the Other/Undecided category by $12.0 \%$. At the $9.5 \%$ level of significance leaving things to 
God also predicts leaving Business majors. Finally, there are no clearly detectable effects of people's beliefs in leaving things up to God and the destinations of those switching majors.

Church influence desirable: The one other measure in the Monitoring the Future database that had an apparent relationship to religiosity was the following question: "Some people think that there ought to be change in the amount of influence and power that certain organizations have in our society. Do you think the following organizations should have more influence, less influence, or about the same amount of influence as they have now? How much influence should there be for churches and religious organizations [much less, less, same as now, more, much more, no opinion]?” Being in a Social Science, Humanities or Engineering major made students significantly more likely to think churches should have less influence in society. Not being on college, at least for the first couple of years after high school, appears to actually make one feel that churches should have more influence in society. As seen in Table 3, it appears that a belief about how influential Churches should be is not related to staying in a major (or out of college). Finally, only switching into Biology (at the 5.5\% level of significance), is significantly related to Church influence on society being seen as desirable. For each one point increase in wanting churches to have more influence and power, there is a $31 \%$ increase in switching into Biology majors, compared to switching into Business majors.

\section{Summary and Conclusions}

The most interesting results are those for three categories of academic majors: Humanities, Social Sciences and Education. Taking the results at face value, Table 4 suggests that there is something attractive about the Humanities to students who are highly religious. This apparent attraction of the Humanities is especially interesting giving the dampening effect of the Humanities on religiosity indicated by Table 2. Thus, students switching into the Humanities are on average more religious, but according to Table 2 come out of the Humanities less religious than they started. However, the type of religiosity that encourages students to switch into the Humanities is the more individualistic importance of religion rather than the measures of support for organized religion (beyond a mild, insignificant positive effect of religious attendance).

According to Table 2, being a Social Science major also seems to make students less religious than they otherwise would be, and according to Table 4 less religious students tend to switch into the Social Sciences. Also, though we did not report these results, these social science students were on average less religious to begin with, so the effect is, in part, one of maintaining or strengthening an existing low religiosity. (It does seem though from Table 3, that as for many other majors, more religious students may stay in the Social Sciences somewhat more.)

All three tables provide very interesting results for Education, which is clearly a safe haven for the religious. As shown in Table 4, highly religious people seem to prefer Education majors. Table 3 suggests that they also tend to stay in that major. In a sense, this is not surprising since Education seems to be the only major that seems to actually increase religiosity relative to what would have happened in a Business major. Thus, highly religious people enter Education majors, stay in them and become more religious.

For the most part, all of the other academic majors are statistically indistinguishable from the Business majors. This large group of majors that are similar to Business majors in their relationship to religiosity confirms the aptness of our choice of Business majors as our reference group.

The results for the "No College" group are also of some interest, with attending college seeming to support positive changes in religious attendance - and conversely, religious attendance seeming to support positive changes in college attendance. 
Our results are thus consistent with the overall theoretical framework guiding this research. We believe that there are important differences among the college majors in world views and overall philosophies of life such as those associated with Science, Developmentalism, and Postmodernism. These world views and philosophies in the various college majors influence the religiosity of students in those majors. At the same time students recognize to some degree the differences among the majors and choose their majors based, at least in part, on religiosity. Most provocatively, our results suggest that Postmodernism, rather than Science, is the bête noir - the strongest antagonist — of religiosity.

We close with several comments about the substantive significance of our results for the late twentieth-century United States. The effects we identify are only differences across majors in the effects of the three streams of thought we identified: Science, Developmentalism and Postmodernism. Since many of the effects of these three streams are common across majors, and pervade society even beyond the ivory tower, we have only been pointing to the tip of the iceberg. Moreover, we measured the differences in effects on one cohort of students. It is likely that many of the effects of Science, Developmentalism and Postmodernism are cumulative over time, with the beliefs of one generation serving as the starting place for the next generation. Finally, it is important to point out that the cultural elites in America and even America's religious elites are drawn from those who have received higher education. Thus the nature and strength of the religiosity of the college-educated elites can serve as an important propagation mechanism for the evolution of religiosity in the world beyond the ivory tower. 


\section{References}

Alwin, Duane F., 1989. "Problems in the Estimation and Interpretation of the Reliability of Survey Data." Quality and Quantity 23:277-331.

Alwin, Duane F., 1994. "Aging, Personality, and Social Change: The Stability of Individual Differences Over the Adult Life Span." Life-Span Development and Behavior, vol. 12, Eds. David L. Featherman, Richard M. Lerner, and Marion Perlmutter. Hillsdale, NJ: Lawrence Erlbaum Associates, Inc. Publishers.

Alwin, Duane F. and Jon A. Krosnick. 1985. "The Measurement of Values in Surveys: A Comparison of Ratings and Rankings.” Public Opinion Quarterly 49(4): 535-552.

Alwin, Duane F., Ronald L. Cohen, and Theodore M. Newcomb. 1991. Political Attitudes Over the Life Span: The Bennington Women After Fifty Years. Madison: University of Wisconsin Press.

Axinn, William G. 1993. "The Effects of Children's Schooling on Fertility Limitation." Population Studies 47(3):481-93.

Axinn, William G. and Scott T. Yabiku. 2001. "Social Change, the Social Organization of Families, and Fertility Limitation." American Journal of Sociology 106(5):1219-61.

Bachman, Jerald G., Lloyd D. Johnston, and Patrick M. O'Malley. 2000. Monitoring the Future: A Continuing Study of American Youth. Ann Arbor: University of Michigan, Survey Research Center.

Barber, Jennifer S. 2004. "Community Social Context and Individualistic Attitudes Toward Marriage." Social Psychology Quarterly 67:236-56.

Barro, Robert J., and Rachel M. McCleary, 2002. "Religion and Political Economy in an International Panel," National Bureau of Economic Research Working Paper \#8931.

Barro, Robert J., and Rachel M. McCleary, 2003. "Religion and Economic Growth," National Bureau of Economic Research Working Paper \#9682.

Barro, Robert J., and Rachel M. McCleary, 2006. "Religion and Economy," Journal of Economic Perspectives 20(2) Spring, 49-72.

Beyerlein, Kraig, 2004. "Specifying the Impact of Conservative Protestantism on Educational Attainment," Journal for the Scientific Study of Religion 48(4), 505-518.

Biddle, Bruce J., Barabara J. Bank, and Ricky L. Slavings. 1990. "Modality of Thought, Campus Experiences, and the Development of Values." Journal of Educational Psychology 82(4):671-82.

Blanchflower, David G., and Andrew J. Oswald, 1997. "The Rising Well-Being of the Young," National Bureau of Economic Research Working Paper \#6102.

Bécares, Laia and Castellano Turner. 2004. "Sex, College Major, and Attribution of Responsibility in Empathic Responding to Persons With HIV Infection." Psychological Reports 95:467-76.

Bledsoe, Caroline H. and Barney Cohen. 1993. Social Dynamics of Adolescent Fertility in Sub-Saharan Africa. Washington, D.C.: National Academy Press. 
Bollen, Kenneth A. and Patrick J. Curran. 2004. Latent Curve Models: A Structural Equation Perspective Hoboken, New Jersey: John Wiley and Sons.

Caldwell, John C. and Pat Caldwell. 1997. "What Do We Know About Fertility Transition." Pp. 15-25 in The Continuing Demographic Transition, Eds. Gavin W. Jones, Robert M. Douglas, John C. Caldwell, and Rennie M. D'Souza. Oxford: Oxford University Press.

Chaloupka, Frank J., and Michael Grossman, 1997. "Price, Tobacco Control Policies and Smoking Among Young Adults," Journal of Health Economics 16(3) June, 359-373.

Chaloupka, Frank J., Michael Grossman and John Tauras, 1997. "Public Policy and Youth Smokeless Tobacco Use," Southern Economic Journal, 64(2) October, 503-516.

Cleland, John. 2001. "The Effects of Improved Survival on Fertility: A Reassessment." Pp. 60-92 in Global Fertility Transition, Eds. John B. Casterline and Rodolfo Bulatao. Supplement to Volume 27 of Population and Development Review.

Cleland, John and Christopher Wilson. 1987. "Demand Theories of the Fertility Transition: An Iconoclastic View." Population Studies 41(1):5-30.

Dawkins, Richard, 2006 (1976). The Selfish Gene, $30^{\text {th }}$ Anniversary Edition, Oxford University Press, USA.

Duff, Andrew and Stephen Cotgrove. 1982. "Social Values and the Choice of Careers in Industry." Journal of Occupational Psychology 55:97-107.

Dull, Valerie T., and Laurie A. Skokan, 1995. "A Cognitive Model of Religion's Influence on Health. Journal of Social Issues 51(2) Summer, 49-64.

Durkheim, Emile, 1897. Suicide. Free Press reprint 1997, ISBN 0684836327

Durkheim, Emile, 1915. The Elementary Forms of Religious Life.

Easterlin, Richard A. 1995. "Preferences and Prices in Choice of Career: The Switch to Business, $1972-$ 87." Journal of Economic Behavior and Organization 27(1):1-34.

Easterlin, Richard A. and Eileen M. Crimmins. 1991. "Private Materialism, Personal Self-Fulfillment, Family Life, and Public Interest." Public Opinion Quarterly 55(4):499-533.

Ellison, Christopher, G., 1998. "Introduction to Symposium: Religion, Health and Well-Being," Journal for the Scientific Study of Religion 37(4), 692-694.

Ethington, Corinna A. and Lee M. Wolfle. 1988. "Women's Selection of Quantitative Undergraduate Fields of Study: Direct and Indirect Influences." American Educational Research Journal 25(2):157-75.

Freeman, Richard, 1986. "Who Escapes? The Relation of Churchgoing and Other BAckground Factors to the Socioeconomic Performance of Black Male Youths from Inner-City Tracts," in 
Richard Freeman and Harry Holzer, eds. The Black Youth Employment Crisis. Chicago: University of Chicago Press, 353-76.

Ghimire, Dirgha J., William G. Axinn, Scott T. Yabiku, and Arland Thornton. Forthcoming. "Social Change, Premarital Non-family Experience and Spouse Choice in an Arranged Marriage Society." American Journal of Sociology.

Glaeser, Edward L., and Bryce A. Ward, 2005. "Myths and Realities of American Political Geography," National Bureau of Economic Research Working Paper \#11857.

Goldin, Claudia and Lawrence Katz, 2000. "Education And Income In The Early Twentieth Century: Evidence From The Prairies,” Journal of Economic History, 60(3) September, 782-818.

Goldin, Claudia, and Lawrence F. Katz, 1999. "Human Capital and Social Capital: The Rise of Secondary Schooling in America, 1910 to 1940," Journal of Interdisciplinary History 29 Spring, 683-723.

Gorsuch, Richard L., 1995. "Religious Aspects of Substance Abuse and Recovery," Journal of Social Issues 51(2) Summer, 65-84.

Gruber, Jonathan H., 2005. "Religious Market Structure, Religious Participation, and Outcomes: Is Religion Good for You?" Advances in Economic Analysis \& Policy: Vol. 5: No. 1, Article 5. http://www.bepress.com/bejeap/advances/vol5/iss 1/art5

Guimond, Serge. 1999. "Attitude Change during College: Normative or Informational Social Influence?" Social Psychology of Education 2(3-4):237-61.

Guiso, Luigi, Paola Sapienza and Luigi Zingales, 2002. "People's Opium? Religion and Economic Attitudes," National Bureau of Economic Research Working Paper \#9237.

Guiso, Luigi, Paola Sapienza and Luigi Zingales, 2006. "Does Culture Affect Economic Outcomes?" Journal of Economic Perspectives 20(2) Spring, 23-48.

Heaton, Tim B. and Renata Forste. 1998. "Education as Policy: The Impact of Education on Marriage, Contraception, and Fertility in Colombia, Peru, and Bolivia." Social Biology 45(3-4):194-213.

Heiss, Jerold S. 1960. "Variations in Courtship Progress Among High School Students." Marriage and Family Living 22(2):165-70.

Hill, M. A. and Elizabeth M. King. 1993. "Women's Education in Developing Countries: An Overview." Pp. 1-50 in Women's Education in Developing Countries: Barriers, Benefits, and Policies, Eds. Elizabeth M. King and M. A. Hill. Baltimore, MD: The Johns Hopkins University Press.

Hodgkinson, Shari P. and J. M. Innes. 2001. "The Attitudinal Influence of Career Orientation in First Year University Students: Environmental Attitudes as a Function of Degree Choice." The Journal of Environmental Education 32(3):37-40.

Hogner, Robert H., 1996. "Speaking in Poetry: Community Service-Based Business Education." Journal of Business Ethics 15(1):33-43. 
Hume, David, 1757. The Natural history of Religion, edited by J.C.A. Gaskin, Oxford, Oxford University Press, 1993, pp. 182-183.

Iannacone, Laurence, Rodney Stark and Roger Finke, 1998. "Rationality and the Religious Mind," Economic Inquiry July, 373-389.

Inkeles, Alex,1969. "Making Men Modern: On the Causes and Consequences of Individual Change in Six Developing Countries." American Journal of Sociology 75(2):208-25.

Inkeles, Alex and David H. Smith, 1974. Becoming Modern: Individual Change in Six Developing Countries. Cambridge, MA: Harvard University Press.

Jejeebhoy, Shireen J., 1995. Women's Education, Autonomy, and Reproductive Behaviour: Experience from Developing Countries. Oxford: Clarendon Press.

Jennings, M. K., 1993. "Education and Political Development Among Young Adults." Politics and the Individual (2):1-24.

Jöreskog, K. G., 1970. "Estimation and Testing of Simplex Models." British Journal of Mathematical and Statistical Psychology 23:121-45.

Jöreskog, K. G., 1974. "Analyzing Psychological Data by Structural Analysis of Covariance Matrices." Pp. 1-56 in Measurement, Psychophysics, and Neural Information Processing, Eds. D. H. Kranz, R. C. Atkinson, R. D. Luce, and P. Suppes. San Francisco: Freeman.

Kahl, Joseph A. 1968. The Measurement of Modernism. Austin, TX: The University of Texas Press.

Levin, Jeffrey S., and Robert Joseph Taylor, 1998. "Panel Analyses of Religious Involvement and WellBeing in African Americans: Contemporaneous vs. Longitudinal Effects," Journal for the Scientific Study of Religion 37(4), 695-709.

Keister, Lisa A., 2003. "Religion and Wealth: The Role of Religious Affiliation and Participation in Early Adult Asset Accumulation” Social Forces, 81, no. 1 (December), 175-207.

Kimball, Miles, Colter Mitchell, Arland Thornton and Linda Young-DeMarco (2005). "Reciprocal Influences of Education on Values Concerning Family, Careers and Society." Unpublished Working Paper, University of Michigan.

Kimball, Miles, Claudia Sahm, and Matthew Shapiro, 2008. "Imputing Risk Tolerance from Survey Responses," Journal of the American Statistical Association 103 (September), 1028-1038.

Kimball, Miles, and Robert Willis, 2008. "Cognitive Economics and Human Capital Theory," University of Michigan.

King, Valerie and Glen H. Elder. 1998. "Education and Grandparenting Roles." Research on Aging 20(4):450-474.

Kolenko, Thomas A., Gayle Porter, Walt Wheatley, and Marvelle Colby. 1996. "A Critique of Service Learning Projects in Management Education: Pedagogical Foundations, Barriers, and Guidelines." Journal of Business Ethics 15(1):133-42. 
Lehrer, Evelyn, 2004a. "The Role of Religion in Union Formation: An Economic Perspective," Population Research and Policy Review 23, 161-185.

Lehrer, Evelyn L., 2004b. "Religion as a Determinant of Economic and Demographic Behavior in the United States," Population and Development Review 30(4) December, 707-726.

Leppel, Karen, Mary L. Williams, and Charles Waldauer. 2001. "The Impact of Parental Occupation and Socioeconomic Status on Choice of College Major." Journal of Family and Economic Issues 22(4):37394.

Levin, Jeffrey S., and Robert Joseph Taylor, 1998. "Panel Analyses of Religious Involvement and WellBeing in African Americans: Contemporaneous vs. Longitudinal Effects," Journal for the Scientific Study of Religion, 37(4) December, 695-709.

Loveland, Matthew T. 2003. Religious Switching: Preference Development, Maintenance, and Change. Journal for the Scientific Study of Religion 42 (1): 147-157

Manski, Charles F., and Joram Mayshar, 2002. "Private and Social Incentives for Fertility: Israeli Puzzles," National Bureau of Economic Research Working Paper \#8984. Pacula,

Markowitz, Sara, and Michael Grossman, 1996. "Alcohol Regulation and Violence Towards Children," Contemporary Economic Policy, 16(3) July, 309-320.

Mocan, Naci, Erdal Tekin, 2005. “The Determinants of the Willingness to be an Organ Donor," National Bureau of Economic Research Working Paper \#11316.

Montgomery, James D., 1996. "Contemplations on the Economic Approach to Religious Behavior," American Economic Review, 86(2) May, 443-447.

Myers, Scott M., 2004. "Religion and Intergenerational Assistance: Distinct Differences by Adult Children's Gender and Parent’s Marital Status," Sociological Quarterly, 45(1), 67-89.

Newcomb, Theodore M. 1943. Personality and Social Change: Attitude Formation in a Student Community. New York: Dryden Press.

Newcomb, Theodore M., Kathryn E. Koenig, Richard Flacks, and Donald P. Warwick. 1967. Persistence and Change: Bennington College and Its Students After Twenty-Five Years. New York: John Wiley and Sons, Inc.

Pacula, Rosalie L., Michael Grossman, Frank J. Chaloupka, Patrick M. O'Malley, Lloyd Johnston, and Matthew C. Farrelly, 2000. "Marijuana and Youth," National Bureau of Economic Research Working Paper \#7703.

Pacula, Rosalie L., 1998. “Adolescent Alcohol and Marijuana Consumption: Is There Really a Gateway Effect?" National Bureau of Economic Research Working Paper No. 6348.

Phelan, J., B. G. Link, A. Stueve, and R. E. Moore. 1995. "Education, Social Liberalism, and Economic Conservatism: Attitudes Toward Homeless People." American Sociological Review 60(1):126-40. 
Price, V. and Hsu M.-L. 1992. "Public Opinion About AIDS Policies: The Role of Misinformation and Attitudes Toward Homosexuals." Public Opinion Quarterly 56(1):29-51.

Quillian, L. 1996. "Group Threat and Regional Change in Attitudes Toward African-Americans." American Journal of Sociology 102(3):816-60.

Ridener, Larry R. 1999. "Effects of College Major on Ecological Worldviews: A Comparison of Business, Science, and Other Students." Journal of Education for Business 75(1):15-21.

Roof, Wade Clark and William McKinney. 1987. American mainline religion: Its changing shape and future. New Brunswick, NJ: Rutgers University Press.

Schultz, T. P. 1993. "Returns to Women's Education." Pp. 51-99 in Women's Education in Developing Countries: Barriers, Benefits, and Policies, Eds. Elizabeth M. King and M. A. Hill. Baltimore, MD: The Johns Hopkins University Press.

Schwarz, Shalom H., and Sipke Huismans 1995. "Value Priorities and Religiosity in Four Western Religions," Social Psychology Quarterly 58(2) June, 88-107.

Scott, J. and H. Schuman. 1989. "Generations and Collective Memories." American Sociological Review 54:359-81.

Shiarella, Ann H. and Anne M. McCarthy. 2000. "Development and Construct Validity of Scores on the Community Service Attitudes Scale." Educational and Psychological Measurement 60(2):286-300.

Sherkat, Darren E. 2001. Tracking the Restructuring of American Religion: Religious Affiliation and Patterns of Religious Mobility, 1973-1998. Social Forces 79 (4): 1459-1493

Sidanius, Jim, Colette van Laar, Shana Levin, and Stacey Sinclair. 2003. "Social Hierarchy Maintenance and Assortment into Social Roles: A Social Dominance Perspective." Group Processes and Intergroup Relations 6(4):333-52.

Singer, Judith D. and John B. Willett 2003. Applied Longitudinal Data Analysis: Modeling Change and Event Occurrence New York: Oxford University Press.

Smith, Tom W. 1990. Classifying Protestant denominations. Review of Religious Research 31: 225-45.

Stark, Rodney, and William Bainbridge, 1987. A Theory of Religion, Peter Lang Publishing, Inc.

Stark, Rodney, Laurence R. Iannacone and Roger Finke, 1996. "Religion, Science and Rationality," American Economic Review 86(2) May, 433-437.

Stigler, George J. and Gary S. Becker, 1977. "De Gustibus Non Est Disputandum," Amer-. ican Economic Review, LXVII (March), 76-90.

Tauras, John A., and Frank J. Chaloupka, 1999. "Determinants of Smoking Cessation: An Analysis of Young Adult Men and Women," National Bureau of Economics Working Paper \#7262. 
Thistlethwaite, Donald L. 1973. "Accentuation of Differences in Values and Exposures to Major Fields of Study." Journal of Educational Psychology 65(3):279-93.

Thornton, Arland. 2005. Reading History Sideways: The Fallacy and Enduring Impact of the Developmental Paradigm on Family Life. Chicago: University of Chicago Press.

Thornton, Arland, Duane F. Alwin and Donald Camburn, 1983. "Causes and Consequences of Sex-Role Attitudes and Attitude Change," American Sociological Review 48(2) April, 211-227.

Thornton, Arland and Georgina Binstock. 2001. "The Reliability of Measurement and the Cross-Time Stability of Individual and Family Variables." Journal of Marriage and the Family 63(3):881-94.

Thornton, Arland, Georgina Binstock and Dirgha Ghimire. International Networks, Ideas, and Family Change. Paper prepared for presentation at Conference on Ideational Factors in International Family Change, June 3-5, 2004, Ann Arbor, MI 48106.

Thornton, Arland and Hui-Sheng Lin. 1994. Social Change and the Family in Taiwan. Chicago: University of Chicago Press.

Thornton, Arland, William G. Axinn, and Yu Xie. 2007. Marriage and Cohabitation. Chicago: University of Chicago Press.

Tourangeau, Roger, Lance J. Rips, and Kenneth Rasinski. 2000. The Psychology of Survey Response New York: Cambridge University Press.

Ventis, W. Larry, 1995. “The Relationships between Religion and Mental Health,” Journal of Social Issues 51(2) Summer, 33-48.

Williams, David R., David B. Larson, Robert E. Buckler, Richard C. Heckman and Caroline M. Pyle, 1991. "Religion and Psychological Distress in a Community Sample," Soc Sci Med 32(11), 1257-1262.

Wilson, David Sloan, 2002. Darwin's Cathedral : Evolution, Religion, and the Nature of Society, University of Chicago Press.

Zlotkowski, Edward. 1996. "Opportunity for All: Linking Service-Learning and Business Education." Journal of Business Ethics 15(1):5-19. 
Figure 1. Latent Growth Curve of Religiosity Measures with Time Varying College Major

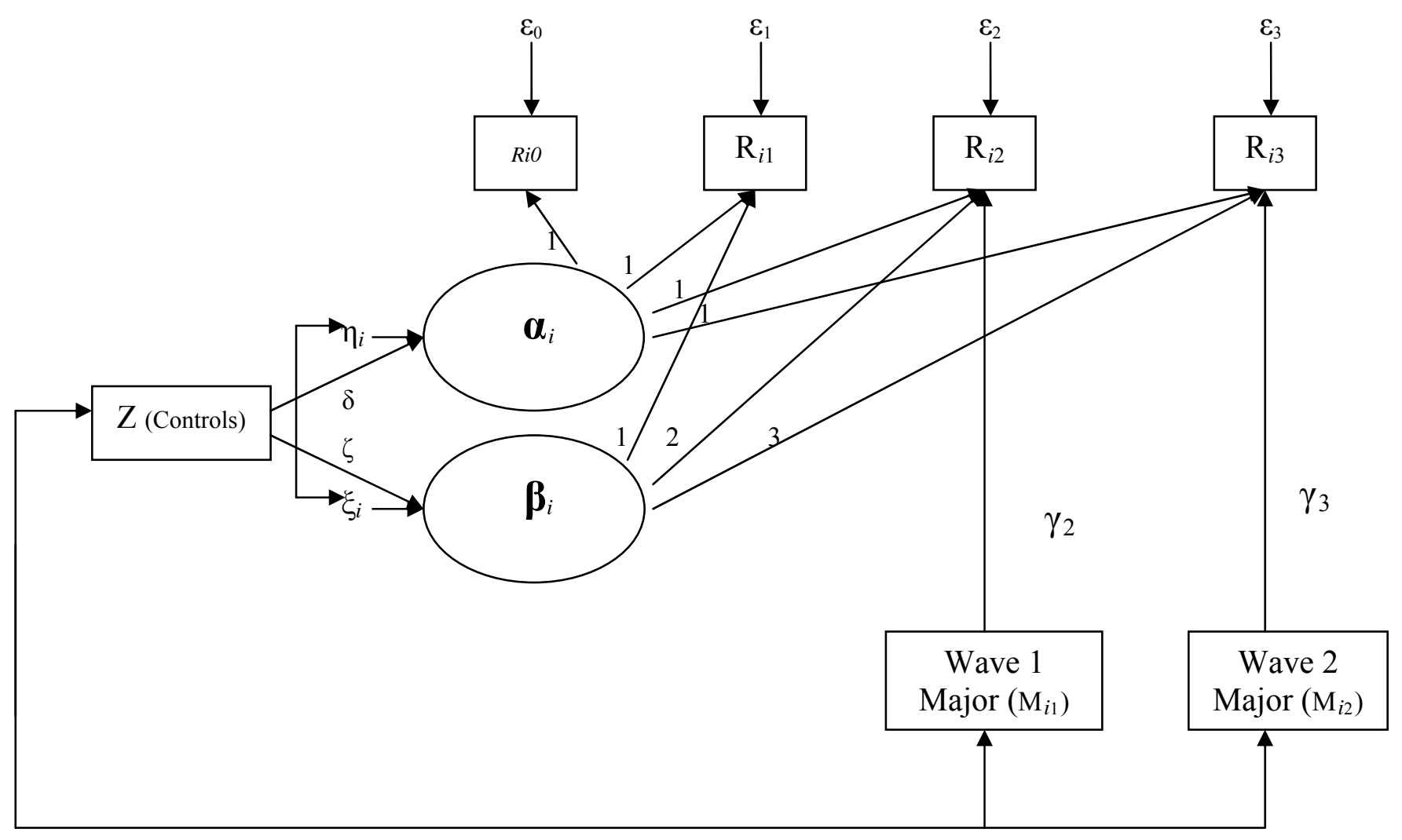


Table 1. Religiosity Question Wording and Means, and Standard Deviations for Base Year, $1^{\text {st }}$ Follow-up, $2^{\text {nd }}$ Follow-up and $3^{\text {rd }}$ Follow-up

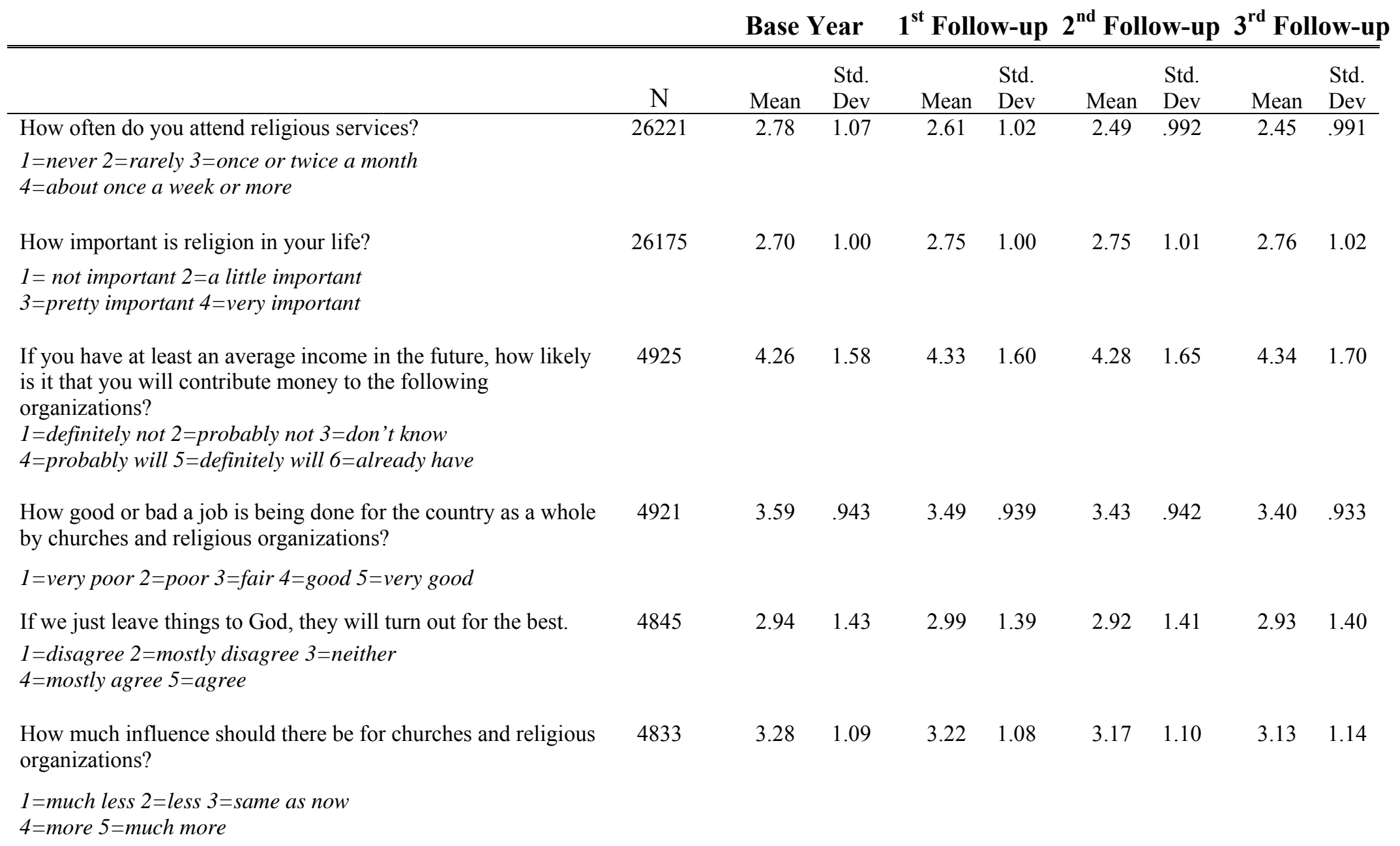


Table 2. Time Varying Effects of College Major in Growth Curve Models of Religiosity

\begin{tabular}{|c|c|c|c|c|c|c|c|c|c|c|c|c|c|}
\hline \multirow{2}{*}{$\begin{array}{l}\text { College } \\
\text { Major }\end{array}$} & \multirow{2}{*}{$\begin{array}{c}\text { Years after } \\
\text { H.S. }\end{array}$} & \multicolumn{2}{|c|}{$\begin{array}{c}\text { Religious } \\
\text { Attendance }\end{array}$} & \multicolumn{2}{|c|}{$\begin{array}{l}\text { Religious } \\
\text { Importance }\end{array}$} & \multicolumn{2}{|c|}{$\begin{array}{c}\text { Giving Money to a } \\
\text { Church }\end{array}$} & \multicolumn{2}{|c|}{$\begin{array}{l}\text { Churches doing a } \\
\text { good job }\end{array}$} & \multicolumn{2}{|c|}{$\begin{array}{l}\text { Leaving things up } \\
\text { to God }\end{array}$} & \multicolumn{2}{|c|}{$\begin{array}{c}\text { Church influence } \\
\text { desirable }\end{array}$} \\
\hline & & Coeff. & $\mathrm{SE}$ & Coeff. & $\mathrm{SE}$ & Coeff. & SE & Coeff. & SE & Coeff. & $\mathrm{SE}$ & Coeff. & SE \\
\hline \multirow{2}{*}{ No College } & $1-2$ & -0.022 & 0.009 & 0.016 & 0.009 & -0.030 & 0.037 & -0.025 & 0.025 & 0.064 & 0.032 & 0.082 & 0.027 \\
\hline & $3-4$ & -0.039 & 0.012 & -0.002 & 0.012 & -0.105 & 0.048 & -0.037 & 0.032 & 0.060 & 0.040 & 0.041 & 0.035 \\
\hline \multirow{2}{*}{ Humanities } & $1-2$ & -0.043 & 0.018 & -0.041 & 0.017 & -0.199 & 0.073 & -0.171 & 0.052 & 0.007 & 0.069 & -0.076 & 0.050 \\
\hline & $3-4$ & -0.055 & 0.018 & -0.058 & 0.018 & -0.263 & 0.076 & -0.132 & 0.050 & -0.081 & 0.065 & -0.149 & 0.051 \\
\hline \multirow{2}{*}{ Social Science } & $1-2$ & -0.061 & 0.017 & -0.049 & 0.017 & -0.200 & 0.068 & -0.145 & 0.051 & -0.124 & 0.063 & -0.190 & 0.049 \\
\hline & $3-4$ & -0.067 & 0.017 & -0.094 & 0.016 & -0.188 & 0.068 & -0.125 & 0.046 & -0.130 & 0.056 & -0.205 & 0.048 \\
\hline \multirow{2}{*}{ Education } & $1-2$ & 0.063 & 0.019 & 0.021 & 0.018 & 0.012 & 0.080 & 0.064 & 0.053 & 0.045 & 0.068 & -0.081 & 0.058 \\
\hline & $3-4$ & 0.086 & 0.019 & 0.039 & 0.019 & -0.025 & 0.080 & -0.017 & 0.051 & 0.042 & 0.064 & 0.047 & 0.057 \\
\hline \multirow{2}{*}{$\begin{array}{c}\text { Biological } \\
\text { Sciences }\end{array}$} & $1-2$ & 0.024 & 0.019 & -0.020 & 0.019 & -0.043 & 0.080 & -0.051 & 0.058 & -0.123 & 0.067 & -0.048 & 0.057 \\
\hline & $3-4$ & -0.009 & 0.021 & -0.029 & 0.020 & -0.045 & 0.086 & -0.125 & 0.058 & -0.119 & 0.068 & 0.007 & 0.062 \\
\hline \multirow{2}{*}{ Phy. Sci/Math } & $1-2$ & 0.026 & 0.020 & -0.038 & 0.020 & 0.032 & 0.081 & $-\mathbf{- 0 . 1 8 7}$ & 0.058 & -0.017 & 0.074 & -0.118 & 0.059 \\
\hline & $3-4$ & 0.007 & 0.024 & -0.049 & 0.024 & -0.083 & 0.097 & -0.119 & 0.070 & -0.115 & 0.079 & -0.092 & 0.071 \\
\hline \multirow{2}{*}{ Engineering } & $1-2$ & 0.002 & 0.018 & -0.001 & 0.018 & 0.078 & 0.076 & 0.008 & 0.055 & -0.084 & 0.068 & -0.172 & 0.054 \\
\hline & $3-4$ & -0.012 & 0.021 & -0.032 & 0.020 & -0.123 & 0.082 & -0.026 & 0.058 & -0.174 & 0.067 & -0.109 & 0.061 \\
\hline \multirow{2}{*}{ Vocational } & $1-2$ & -0.009 & 0.016 & -0.003 & 0.016 & -0.057 & 0.067 & -0.015 & 0.047 & 0.105 & 0.061 & 0.075 & 0.046 \\
\hline & $3-4$ & -0.019 & 0.017 & 0.027 & 0.016 & -0.121 & 0.068 & -0.002 & 0.045 & 0.004 & 0.057 & 0.043 & 0.048 \\
\hline Other/ & $1-2$ & -0.015 & 0.009 & -0.008 & 0.009 & -0.090 & 0.038 & -0.081 & 0.027 & -0.042 & 0.034 & -0.044 & 0.028 \\
\hline Undecided & $3-4$ & -0.020 & 0.011 & 0.016 & 0.011 & -0.160 & 0.046 & -0.057 & 0.031 & 0.011 & 0.039 & -0.038 & 0.034 \\
\hline \multicolumn{2}{|l|}{$\mathrm{N}$} & \multicolumn{2}{|c|}{26221} & \multicolumn{2}{|c|}{26175} & \multicolumn{2}{|c|}{4925} & \multicolumn{2}{|c|}{4921} & \multicolumn{2}{|c|}{4845} & \multicolumn{2}{|c|}{4833} \\
\hline \multicolumn{2}{|l|}{ AIC } & \multicolumn{2}{|c|}{49428.330} & \multicolumn{2}{|c|}{48716.542} & \multicolumn{2}{|c|}{10172.329} & \multicolumn{2}{|c|}{9851.598} & \multicolumn{2}{|c|}{9714.477} & \multicolumn{2}{|c|}{9714.583} \\
\hline RMSE & & 0.10 & & 0.1 & & 0.1 & & 0.1 & & & & 0.1 & \\
\hline Tucker-Lewis & & 0.47 & & 0.4 & & 0.4 & & 0.4 & & & & 0.4 & \\
\hline Incremental Fit & dex & 0.85 & & 0.8 & & 0.8 & & 0.8 & & & & 0.8 & \\
\hline
\end{tabular}

* Bolded and Italicized values are significant at the $p<0.05, p<.0 .1$ level of significance, respectively. Our analyses control for the year of initial survey, region, gender, race, parental education, and religion by using covariates to predict the underlying growth curve model for each measure of religiosity. 
Table 3. $1^{\text {st }}$ Follow-up Religiosity Predicting the Stability of College Major from the $\mathbf{1}^{\text {st }}$ to the $3^{\text {rd }}$ Follow-up (coefficients are log-odds)

\begin{tabular}{|c|c|c|c|c|c|c|c|c|c|c|c|c|c|c|c|}
\hline \multirow[b]{2}{*}{ Variables } & \multicolumn{3}{|c|}{ Not in College } & \multicolumn{3}{|c|}{ Humanities } & \multicolumn{3}{|c|}{ Social Science } & \multicolumn{3}{|c|}{ Education } & \multicolumn{3}{|c|}{ Biological Sciences } \\
\hline & $\mathrm{N}$ & Coeff. & $\mathrm{SE}$ & $\mathrm{N}$ & Coeff. & SE & $\mathrm{N}$ & Coeff. & SE & $\mathrm{N}$ & Coeff. & SE & $\mathrm{N}$ & Coeff. & SE \\
\hline Religious Attendance & 8071 & -0.151 & 0.026 & 1355 & -0.019 & 0.061 & 1442 & 0.106 & 0.061 & 1229 & 0.127 & 0.076 & 1108 & 0.120 & 0.067 \\
\hline Religious Importance & 8047 & -0.083 & 0.027 & 1348 & 0.009 & 0.059 & 1445 & 0.055 & 0.060 & 1228 & 0.215 & 0.082 & 1107 & 0.061 & 0.068 \\
\hline Giving Money to a Church & 1552 & 0.066 & 0.037 & 250 & -0.124 & 0.089 & 289 & -0.035 & 0.089 & 205 & 0.180 & 0.132 & 206 & 0.090 & 0.101 \\
\hline Churches doing a good job & 1557 & -0.063 & 0.060 & 246 & -0.031 & 0.142 & 256 & -0.050 & 0.150 & 238 & 0.108 & 0.206 & 197 & -0.262 & 0.192 \\
\hline Leaving things up to God & 1545 & 0.091 & 0.044 & 213 & -0.005 & 0.125 & 253 & -0.023 & 0.104 & 228 & 0.188 & 0.160 & 223 & 0.071 & 0.109 \\
\hline Church Influence Desirable & 1453 & -0.083 & 0.059 & 277 & -0.150 & 0.129 & 289 & 0.175 & 0.132 & 202 & 0.059 & 0.176 & 203 & 0.004 & 0.151 \\
\hline
\end{tabular}

\begin{tabular}{|c|c|c|c|c|c|c|c|c|c|c|c|c|c|c|c|}
\hline \multirow[b]{2}{*}{ Variables } & \multicolumn{3}{|c|}{ Phy. Sciences/Math } & \multicolumn{3}{|c|}{ Engineering } & \multicolumn{3}{|c|}{ Vocational } & \multicolumn{3}{|c|}{ Business } & \multicolumn{3}{|c|}{ Other/Undecided } \\
\hline & $\mathrm{N}$ & Coeff. & SE & $\mathrm{N}$ & Coeff. & SE & $\mathrm{N}$ & Coeff. & SE & $\mathrm{N}$ & Coeff. & SE & $\mathrm{N}$ & Coeff. & SE \\
\hline Religious Attendance & 986 & -0.099 & 0.073 & 1283 & 0.076 & 0.069 & 1639 & -0.108 & 0.063 & 3114 & 0.087 & 0.049 & 5994 & -0.035 & 0.029 \\
\hline Religious Importance & 988 & -0.100 & 0.071 & 1292 & 0.031 & 0.068 & 1639 & -0.067 & 0.068 & 3110 & -0.048 & 0.050 & 597 & -0.060 & 0.029 \\
\hline Giving Money to a Church & 194 & -0.193 & 0.110 & 240 & 0.038 & 0.108 & 302 & -0.069 & 0.101 & 558 & 0.115 & 0.073 & 1129 & 0.038 & 0.043 \\
\hline Churches doing a good job & 190 & -0.047 & 0.176 & 227 & 0.332 & 0.162 & 303 & -0.012 & 0.146 & 613 & 0.016 & 0.115 & 1094 & 0.020 & 0.72 \\
\hline Leaving things up to God & 177 & 0.031 & 0.130 & 227 & -0.158 & 0.130 & 283 & 0.221 & 0.136 & 579 & -0.153 & 0.090 & 1117 & 0.113 & 0.051 \\
\hline Church Influence Desirable & 184 & -0.163 & 0.157 & 238 & 0.021 & 0.166 & 327 & -0.182 & 0.142 & 575 & 0.033 & 0.118 & 1085 & -0.054 & 0.064 \\
\hline
\end{tabular}

*Bolded and Italicized values are significant at the $\mathrm{p}<0.05, \mathrm{p}<0.1$ level of significance, respectively. Our analyses control for the year of initial survey, region, gender, race, parental education, and religion. 
Table 4. Multinomial Logistic Regressions Predicting the $3^{\text {rd }}$ Follow-up College Major from the $1^{\text {st }}$ Follow-up Religiosity measure for those in College at $1^{\text {st }}$ Follow-up Who Indicated a Change in College Major by $3^{\text {rd }}$ Follow-up (coefficients are log odds).

\begin{tabular}{|c|c|c|c|c|c|c|c|c|c|c|c|c|c|c|c|c|c|}
\hline \multirow[b]{2}{*}{ Variables } & \multirow[b]{2}{*}{$\mathbf{N}$} & \multicolumn{2}{|c|}{ Humanities } & \multicolumn{2}{|c|}{ Social Science } & \multicolumn{2}{|c|}{ Education } & \multicolumn{2}{|c|}{ Biology } & \multicolumn{2}{|c|}{$\begin{array}{c}\text { Physical Sci./ } \\
\text { Math }\end{array}$} & \multicolumn{2}{|c|}{ Engineering } & \multicolumn{2}{|c|}{ Vocational } & \multicolumn{2}{|c|}{ Other/Undecided } \\
\hline & & Coeff. & SE & Coeff. & SE & Coeff. & SE & Coeff. & SE & Coeff. & SE & Coeff. & SE & Coeff. & $\mathrm{SE}$ & Coeff. & SE \\
\hline $\begin{array}{c}\text { Religious } \\
\text { Attendance }\end{array}$ & 6641 & 0.082 & 0.053 & -0.082 & 0.048 & 0.104 & 0.052 & 0.079 & 0.060 & -0.100 & 0.068 & 0.039 & 0.071 & -0.069 & 0.054 & -0.027 & 0.044 \\
\hline $\begin{array}{c}\text { Religious } \\
\text { Importance }\end{array}$ & 6624 & 0.158 & 0.053 & 0.004 & 0.048 & 0.161 & 0.053 & 0.123 & 0.060 & -0.022 & 0.068 & 0.031 & 0.070 & 0.035 & 0.054 & 0.021 & 0.044 \\
\hline $\begin{array}{c}\text { Giving Money to } \\
\text { a Church }\end{array}$ & 1256 & -0.041 & 0.077 & -0.002 & 0.070 & 0.160 & 0.082 & -0.006 & 0.088 & -0.187 & 0.099 & 0.007 & 0.101 & 0.023 & 0.079 & 0.004 & 0.065 \\
\hline $\begin{array}{l}\text { Churches doing a } \\
\text { good job }\end{array}$ & 1239 & -0.297 & 0.120 & -0.131 & 0.112 & 0.242 & 0.128 & 0.127 & 0.148 & -0.166 & 0.163 & 0.036 & 0.173 & 0.019 & 0.129 & -0.024 & 0.103 \\
\hline $\begin{array}{l}\text { Leaving things up } \\
\text { to God }\end{array}$ & 1146 & -0.094 & 0.101 & -0.112 & 0.085 & 0.024 & 0.097 & 0.076 & 0.105 & -0.006 & 0.115 & -0.024 & 0.117 & 0.127 & 0.092 & 0.001 & 0.080 \\
\hline $\begin{array}{c}\text { Church Influence } \\
\text { Desirable }\end{array}$ & 1230 & -0.074 & 0.111 & -0.151 & 0.105 & 0.079 & 0.113 & 0.270 & 0.141 & 0.066 & 0.148 & -0.091 & 0.152 & -0.141 & 0.119 & -0.142 & 0.095 \\
\hline
\end{tabular}

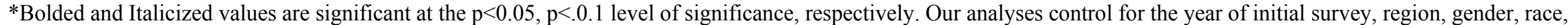
parental education, and religion. 